\title{
Possible Health Assessment For Heavy Metal Concentration in Water, Sediment, and Fish Species and Pregnant Women's Biomonitoring in Miankaleh Peninsula, Iran
}

Abbas Esmaili-sari ( $\square$ esmaili@modares.ac.ir)

Tarbiat Modares University

\section{Zahra Shaabani}

Islamic Azad University of Tehran: Islamic Azad University Central Tehran Branch

Ali Mashinchian Moradi

Islamic Azad University of Tehran: Islamic Azad University Central Tehran Branch

Lobat Taghavi

Islamic Azad University of Tehran: Islamic Azad University Central Tehran Branch

Forough Farsad

Islamic Azad University Bandar Abbas Branch

\section{Research Article}

Keywords: Heavy metals, Risk assessment, Human bio monitoring, Pregnant Women, Miankaleh peninsula

Posted Date: September 28th, 2021

DOl: https://doi.org/10.21203/rs.3.rs-876746/v1

License: (c) (1) This work is licensed under a Creative Commons Attribution 4.0 International License. Read Full License 


\section{Abstract}

A human bio monitoring study, investigating most consumed fish species exposure to heavy metals was done in northern part of Iran, Miankale Peninsula, in winter 2019. Metals levels were evaluated in various tissues of fish, as well as Turkmen pregnant women's biological indicators. For this purpose, 20 water and sediment, 14 fish and 16 human samples were collected. Concentration of $\mathrm{Cr}, \mathrm{Co}, \mathrm{Cu}, \mathrm{As}, \mathrm{Hg}$ and $\mathrm{Pb}$ metals were determined by ICP-MS device. The highest mean concentration of $\mathrm{Cu}$ and $\mathrm{Cr}$ in water (93.35 and $80.91 \mu \mathrm{g} / \mathrm{l}$ respectively), $\mathrm{Hg}$ and $\mathrm{Pb}$ in sediment ( $7.4 \mu \mathrm{g} / \mathrm{g}$ for both), $\mathrm{Cu}$ and $\mathrm{Pb}$ in liver (27 and18.9 $\mu \mathrm{g} / \mathrm{g}$ for C.carpio; 1414 and $31.7 \mu \mathrm{g} / \mathrm{g}$ for L.auratus), muscle (10 and 18.8 for C.carpio; 37.2 and 8.27 $\mu \mathrm{g} / \mathrm{g}$ for L.auratus), and skin (26.4 and 9.9 for C.carpio; 10.8 and $11.74 \mu \mathrm{g} / \mathrm{g}$ for L.auratus) of both fish species, and Cu in blood $(2.53 \mathrm{mg} / \mathrm{l})$, hair $(8.87 \mu \mathrm{g} / \mathrm{g})$, fingernail $(36.46 \mu \mathrm{g} / \mathrm{g})$, and toenail $(29.04 \mu \mathrm{g} / \mathrm{g})$ samples were observed, while Co had the lowest concentration in all samples. Liver in fish samples and fingernail in pregnant women were the tissues with the highest heavy metals accumulation, whereas the lowest concentrations of heavy metals were observed in the muscles of fish species and pregnant women's blood sample. Hg concentration in water and sediments, the muscle of fish, and pregnant women's blood and hair samples were higher than the values suggested by various organizations. This study showed that the level of heavy metals, especially $\mathrm{Hg}$, in water, sediments and fish is a threat to human health. Therefore, it is recommended that the necessary information about the consumption of seafood with high amounts of $\mathrm{Hg}$ should be provided in this area.

\section{Introduction}

In the recent decades, industrial and urban development and efforts to improve living conditions and access to energy have led to the release of chemical pollutants, resulting in major environmental concerns (Ezemonye, Adebayo et al. 2019). Water is one of the important parts of the environment the quality of which has been affected by various human activities (Coffie 2015). Among various pollutants, heavy metals pose a serious threat in ecosystem health due to their high stability (Vrhovnik, Arrebola et al. 2013; Ogbomida, Nakayama et al. 2018). Although these metals enter the aquatic environment naturally through rocks weathering, the main source of metals in aquatic environment is industrial, mine, and agricultural activities, as well as, municipal wastewater (Walker, Hopkin et al. 2001; Asante 2015); therefore, lakes are the main place for restoring heavy metals directly and indirectly (Elkady,Sweet et al. 2015). Heavy metals can accumulate through the food chain in marine organisms due to their nondegradability and stability in water and sediment samples (Javed and Usmani 2016; Ullah, Maksud et al. 2017; Fuentes-Gandara and Herrera-Herrera et al. 2018).

Metals concentration in water and sediment samples play an important role in the bioavailability of heavy metals, but do not provide enough information about the state of the ecosystem ; therefore, the use of biomarkers is essential. Fish are at the highest level of the marine food chain, and they are reliable biomarkers for monitoring heavy metal pollution in aquatic ecosystems (Varol and Sünbül 2019). So the concentration of metals in fish tissue can be much higher than their concentration in water (Usero,Izquierdo et al. 2004). On the one hand, a large amounts of heavy metals accumulate in the various 
organs and tissues of fish through suspended particles in water, food, ion exchange in lipophilic membranes (e.g. gills) over time, which can be harmful to human health (Dadar, Adel et al. 2016; Ezemonye, Adebayo et al. 2019; Varol and Sünbül 2019). On the other hand, fish is considered as an animal source of protein for human (37\% of total animal protein) (Food 2018), which is highly recommended due to its high levels of fatty acids, especially omega-3, protein, vitamins and minerals (Adel, Dadar et al. 2016; Basim and Khoshnood 2016; Fuentes-Gandara, Herrera-Herrera et al. 2018). Eating fish, at least twice a week, can reduce the risk of heart attack (Kris Etherton et al. 2002; Fallah, SaeiDehkordi et al. 2011). Evidences also show that fish consumption is increasing, with global per capita consumption rising from $9.9 \mathrm{~kg}$ in 1960 to $14.4 \mathrm{~kg}$ in 1990 and $19.7 \mathrm{~kg}$ in 2013(Bianchi, Chopin et al. 2014). The amount of metals in the edible parts of fish is important for human health, because of the consumption of contaminated fish (Varol and Sünbül 2020). Besides, the overuse of this beneficial nutrient is a major path of heavy metals transmission to human body (Ahmed, Baki et al. 2016, Basim and Khoshnood 2016).

Diet is the most important route for heavy metals to enter human body (Zhuang, McBride et al. 2009). Despite the importance of fish consumption, it can be a serious threat to human health owing to the possibility of high heavy metals concentration (Varol, Kaya et al. 2017), hence, the potential risk assessment of metals in fish consumption is necessary (Garnero, de los Angeles Bistoni et al. 2020). Since heavy metals can have carcinogenic and non-carcinogenic effects on humans(Varol, Kaya et al. 2017), there are several ways to assess the health risk of carcinogens and non-carcinogens due to the exposure to toxic metals by fish (Saha, Mollah et al. 2016, Griboff, Wunderlin et al. 2017). The target hazard quotient (THQ) and Carcinogenic Risk (CR) are suggested by the US Environmental Protection Agency to assess the potential non-carcinogenic and carcinogenic risk associated with the use of heavy metal-contaminated fish (Basim and Khoshnood 2016). Many researchers have used these methods to investigate the carcinogenic and non-carcinogenic effects of heavy metals(Atique Ullah, Akter et al. 2019, Esilaba, Moturi et al. 2020, Garnero, de los Angeles Bistoni et al. 2020, Kortei, Heymann et al. 2020, Sadeghi, Loghmani et al. 2020).

Typically, human health risk in terms of chemicals is estimated by using default methods of exposure and measuring pollutants in various sources. These methods may not be accurate enough and estimate the amounts less or more than the real exposure. For example, it may examine only one of the sources or pathways of the contaminants entering the body.in this case, the estimated amount is less than the actual amount. Nevertheless, human biological monitoring (HBM) includes all the pollutants entering from different sources and different pathways and provides a better estimation of the possible amount of the pollutants in the human body (Cherrie, Semple et al. 2006). Therefore, human biomonitoring assessment contributes to the calculation of the total amount of heavy metals entering from different sources and routes, the environmental conditions of the region, distribution of exposure to different population groups, identification of vulnerable groups, identification of highly infected areas as well as a better estimation of health assessment (Cherrie, Semple et al. 2006, Angerer, Ewers et al. 2007, Clewell, Tan et al. 2008, Angerer, Aylward et al. 2011, Louro, Heinälä et al. 2019, Faure, Noisel et al. 2020). Bio monitoring is a direct measurement of chemicals in biological samples, such as blood, serum, urine, hair, nails, and saliva 
of an organism which have been exposed to contaminants (LaKind, Aylward et al. 2008, Hays and Aylward 2009, Lemos, Novaes et al. 2009, Angerer, Aylward et al. 2011). Studies have shown that various factors, such as age, sex, body weight, geographical factors, time of exposure, workplace, diet, smoking, sanitation, health conditions, or the consumption of vitamin and mineral supplements affect the bioaccumulation of heavy metals in human body (Christensen 1995, Marrugo-Negrete, Ruiz-Guzmán et al. 2013, Alrobaian and Arida 2019, Al-Saleh 2020). However, the main focus is on pregnant women, because women are highly vulnerable during pregnancy period; in addition, developing children and fetuses are extremely sensitive to pollutants (Vahter, Berglund et al. 2002).

The US National Academies of Sciences, Engineering, and Medicine in recent report, entitled "Using the 21 st Century Science to Improve Risk-Related Evaluations" (USNAS 2017), considers human biological monitoring as an essential tool for human exposure to chemical substances (http://foodmetabolome.org). In addition, Under the authority of the European Union (EU), the Horizon2020 European Joint Program HBM4EU (2017-2021) established more accurate evidence of human exposure to chemicals with the aim of minimizing human health risk involves evaluating human biological monitoring (Ganzleben, Antignac et al. 2017). In Canada, a human bio monitoring program has been established in collaboration with Canadian Health Measures Survey (CHMS) and the Public Health Agency of Canada, measuring 250 chemical contaminants in biological monitoring components, such as blood, urine, and hair over the ages of 3 to 79 (Canada 2010, Canada 2013, Canada 2017, Haines, Saravanabhavan et al. 2017, Eykelbosh, Werry et al. 2018).

Miankaleh International Wetland is a unique habitat for wintering migratory birds and aquatic reproduction. In addition, it plays an important role in feeding local people. Despite the high use of seafood by the locals in the area, there is no basic knowledge about the levels of heavy metals in various human tissues. The aim of this study is monitoring $\mathrm{Cr}, \mathrm{Co}, \mathrm{Cu}, \mathrm{As}, \mathrm{Hg}$, and $\mathrm{Pb}$ metals in water and sediment samples as well as measuring heavy metals concentration in $C$. carpio and $L$. auratus fish species to estimate the health risks of heavy metals in relation to fish consumption. Moreover, for the first time, biological monitoring of heavy metals in pregnant women's hair, blood, fingernail, and toenail is performed in two areas named Chapaqli and Qaraesou around the wetland. we also tried to investigate socio demographic and lifestyle factors which may have changed the levels of these heavy metals in pregnant women's organs.

\section{Material And Methods}

\section{Study area}

Miankaleh Peninsula, which is known as a Wildlife Refuge and Biosphere Reserve, is situated in the southeastern region of the Caspian Sea with geographical coordinates of $36^{\circ} 50^{\prime} \mathrm{N} 053^{\circ} 17^{\prime} \mathrm{E}$ and surface area of $96,678.5$ hectares. Miankaleh was determined a Ramsar site in 1975. It includes two parts, water and land environment, and as a result of the Caspian Sea water retreat, it has been separated from the bay and the sea in the form of a sandy and saline lands. It is nearly $60 \mathrm{~km}$ long with an average width of 
$2.5 \mathrm{~km}$ and $6.5 \mathrm{~km}$ in its downstream and upstream sections, respectively. The mean elevation is about $28-10$ meters below the sea level, the annual rainfall is approximately $700 \mathrm{~mm}$, and the temperature is about 17 degrees Celsius. Due to its unique features, it is a worthy place for migratory birds and breeding aquatic animals to spend the winter, consequently, about half a million migratory birds migrate from Siberia to this region every year. 47 species of birds, 24 species of fish, 27 genera of phytoplankton, and 5 genera of benthos have been identified in this area. Presence of food, chemical, metal, and non-metallic industrial units around the wetland as well as the location of oil reservoirs and hydrocarbon activities have affected the wetland and caused physical, chemical, and biological pollution of the wetlands and surrounding rivers(Ramsar 1975, UNESCO 1976).

\section{Field sampling}

10 water and sediment sampling sites of study area were chosen including Qalepayan (S1), Miankaleh center (S2), Galougah(S3), Bandargaz(S4), Esmailsay(S5), Qaraesou (S6), Bandartorkman(S7), Chapaqli (S8),Khozeini channel (S9) and Ashourade(S10) (Fig. 1). Water and sediment sampling was taken at each station with three replications in the winter 2019. Ruttner Water and Ekman-Grab sampler were applied for gathering surface water and sediment samples respectively. Water samples were fixed with $5 \mathrm{ml} 70 \%$ nitric acid and stored in an iced cool box so as to analyze metals and sediment samples were preserved in plastic bags for drying and analysis.14 fish samples were bought from 9 fish markets of Ashourade, Bandar Torkman, Chapaqli, Qaraesou, Qhalepayan, Galougah, Esmailsay, Khozeini channel, and Miankale center. Furthermore, Human biomonitoring was performed based on the protocol specified by the Medical Ethical Committee of Iran in collaboration with the staff of the health center (Ethical Committee of Golestan University of Medical Sciences.(IR.GOUMS.REC.2019.126). Ethical principles and privacy were fully observed, and a written consent was received from the participants while completing the questionnaire. Blood, hair, fingernail, and toenail samples were taken from 16 Turkmen pregnant women from two sites including Chapaqli and Qaraesou.

\section{Sample preparation for heavy metal analysis}

Water and sediment sample preparation was done according to the modified EPA digestion method (EPA $3005 a$ and EPA 3050B respectively). First, suspended particulate matters were removed from water samples by using a Whatman no. $1(0.45 \mathrm{~mm})$ filter paper. $10 \mathrm{~mL} \mathrm{HNO}{ }_{3}(65.0 \%)$ was added into $100 \mathrm{ml}$ of the water sample and then heated on a hot plate at 90 to $95^{\circ} \mathrm{C}$ until the volume reached $15-20 \mathrm{ml}$. Then, samples were moved in a $100 \mathrm{ml}$ volumetric flask and smoothed through Whatman glass filter paper (pore size $110 \mathrm{~mm}$ ) prior to the analysis. Sediment samples were dried in an oven at $105^{\circ} \mathrm{C}$ for 24 hours. Afterwards, $0.5 \mathrm{~g}$ of each sample was digested by the combination of nitric acid (69\%), hydrochloric acid (37\%), and hydrogen peroxide (30\%) in a ratio of 1: 1: 2 with continual heating. After dilution, the samples were passed through Whatman No. 41 filter paper.

Purchased fish were transferred to the laboratory in cold flask, their species were identified, and autopsies were carried out to determine the metals concentration in liver, muscle, and skin tissues of fish samples. One gram of samples was put into microwave digestion tubes and $5 \mathrm{ml} \mathrm{HNO}_{3}(65 \%)$ and $1 \mathrm{ml} \mathrm{H}_{2} \mathrm{O}_{2}$ were 
added to each tube (U.S. EPA-3052, 1996). Thermal decomposition was used to determine the concentration of total mercury $(\mathrm{Hg})$ in fish tissues following the U.S. Environmental Protection Agency recommendations- EPA 7473 (1998).

For human bio monitoring, Turkmen pregnant women's sampling was performed in two villages, Chapaqli and Qaraesou. Hair samples from the occipital area of the scalp and fingernail and toenail samples were picked up with a pair of sterilized stainless steel scissors. All the samples were placed in plastic bags prior to analysis. Furthermore, $5 \mathrm{~mL}$ blood samples were taken by nonmetal needles and test tubes based on specific protocols. For analysis, all specimens were transferred to the laboratory in containers labeled with the subject identification number and date. Hair (3g) and Nail (1g) samples were kept in an oven at $110^{\circ} \mathrm{C}$ for 1 hour and $550^{\circ} \mathrm{C}$ for 4 hour respectively and finally maintained in a desiccator pending analysis. The produced ash was digested with $10 \mathrm{ml}$ of $6: 1$ mixture of concentrated nitric acid and perchloric acid; the mixture was warmed up for perfect vaporization to gain a water transparent solution. Each digested samples was moved into a $100 \mathrm{~mL}$ volumetric flask and reached the specified volume with distilled water (Abdulrahman, Akan et al. 2012). $4 \mathrm{~mL}$ of $\mathrm{HNO}_{3}(69 \%)$ and $2 \mathrm{~mL}$ of $\mathrm{H}_{2} \mathrm{O}_{2}(35 \% \mathrm{w} / \mathrm{v})$ were used to digest blood samples in the microwave digestion system in $200^{\circ} \mathrm{C}$ for 10 minutes (Alrobaian and Arida 2019). Finally, the analysis of metals $(\mathrm{Cr}, \mathrm{Co}, \mathrm{Cu}, \mathrm{As}, \mathrm{Hg}$ and $\mathrm{Pb}$ ) in surface water, sediments, fish, and human tissues was done by ICP-MS device (HP-4500 model) equipped with Asx-520 auto-sampler.

\section{Human health risk assessment}

\section{Target Hazard Quotients}

Target Hazard Quotients provided by the US Environmental Protection Agency was used to calculate the risk for the people with non-carcinogenic diseases according to Formula1(EPA 2004, IRIS 2010).THQ higher and lower than 1 indicates a high probability and non-probability of a potential risk. The Total Target Hazard Quotients (TTHQ) is obtained from the sum of all metals, according to Formula 2(Chien, Hung et al. 2002).

$$
T H Q=\frac{E F * E D * I R * C}{B W * R f D * A T} * 10^{-3}
$$

$T T H Q=\sum_{i=1}^{n} T H Q_{i}$

THQ: Target Hazard Quotients;

EF: Frequency of exposure (365 days/year);

ED: Total exposure time (70 years);

IR: Daily consumption rate of fish; $33.15 \mathrm{~g} /$ day based on (Iran Fisheries Organization 1398); 
C: Concentration of metal in muscle tissue of consumed fish ( $\mathrm{mg} / \mathrm{kg}$ wet weight);

Bw: The average of adults body weight (70 kg);

AT: Average exposure days (365 days/year $* 0 y e a r=2550$ days);

RfD: (mg/kg-day); The oral reference dose for $\mathrm{Cr}, \mathrm{Co}, \mathrm{Cu}, \mathrm{As}, \mathrm{Hg}$ and $\mathrm{Pb}$ are 0.003, 0.03, 0.04, 0.0003, 0.0001 and $0.0035 \mathrm{mg} / \mathrm{kg}$ BW/day respectively (USEPA 2011, Finley, Monnot et al. 2012, USEPA 2012, USEPA 2019).

\section{Determination of Estimated daily intake}

The estimated daily intake (EDI) depends on metal and food concentration, and body weight. Two hypotheses have been considered to estimate heavy metals risks caused by fish consumption; cooking has no effect on metals concentration (Cooper, Doyle et al. 1991), the eaten dose is equal to the absorbed dose of the contaminant (USEPA 1989). The estimated amount of daily intake was calculated based on a method proposed by USEPA using formula3(Ikem and Egiebor 2005, Christophoridis, Kosma et al. 2019).

$$
E D I=\frac{C^{*} I R_{D}}{B W}
$$

EDI: Estimation of Daily intake of metals through fish consumption ( $\mathrm{mg} / \mathrm{kg}$ body weight/day);

C: Concentration of metal in muscle tissue of the consumed fish ( $\mathrm{mg} / \mathrm{kg}$ wet weight);

IR ${ }_{D}$ : (intake rate) Daily consumption rate of fish; $33.15 \mathrm{~g} /$ day based on (1ran Fisheries Organization 1398);

Bw: The average of adults' body weight $(70 \mathrm{~kg})$.

\section{Carcinogenic Risk}

According to EPA standards, the life expectancy or number of years that a person is exposed to dangerous pollutants is equal to 70 , which is used in the calculations related to carcinogenic and non-carcinogenic effects (Jeszka-Skowron, Zgoła-Grześkowiak et al. 2017). In order to assess the risk of cancer in a person, it is necessary to take all the factors into account. To evaluate the carcinogenic effects of the exposure to carcinogenic heavy metals studied by swallowing, CR was calculated based on EPA and through the Eq. 4. In this equation, CR is Carcinogenic Risk and CFS shows Carcinogenic Slope Factors for the substance (ATSDR 2010, Feed 2013, Wei, Wang et al. 2020). Carcinogenic risk index between $10^{-6}$ (risk of carcinogenic during human life 1 in 1,000.000) and $10^{-4}$ (risk of carcinogenic during human life 1 in $10,000)$ indicates a range of potential risks predicted for the causes of cancer. Therefore, chemicals with a risk factor of less than $10^{-6}$ are not considered as the chemicals of concern (Demirezen and Aksoy 2006, Liu, Liang et al. 2006, USEPA 2015). Relevant calculations were performed based on the standard 
assumptions proposed by USEPA. According to this standard, the amount of CSF for the $\mathrm{Cr}, \mathrm{As}$, and $\mathrm{Pb}$ was equal to $0.5,1.5$, and $0.0085 \mathrm{mg} / \mathrm{kg} /$ day, respectively (Demirezen and Aksoy 2006).

$C R=E D{ }^{*} C S F$

\section{Statistical Analysis}

Statistical test analysis was carried out using R software. First, descriptive statistics of heavy metal concentration in water, sediment, fish, and human samples were determined; furthermore, an independent sample T test, one-way analysis of variance (ANOVA), and Pearson tests were used to evaluate the significant differences in metal concentration and correlations in the data.

\section{Results And Discussion}

\section{Heavy metals concentration in water and sediment}

Water and sediment samples were collected at 10 stations to determine the concentration of heavy metals chromium, Cobalt, Copper, Arsenic, Mercury, and lead. The overall mean concentration of the metals in the surface water were $44.56 \pm 5.9 \mu \mathrm{g} / \mathrm{L} \mathrm{Cr}, 10 \pm 0.17 \mu \mathrm{g} / \mathrm{L} \mathrm{Co}, 69.03 \pm 13.37 \mu \mathrm{g} / \mathrm{L} \mathrm{Cu}, 8.79 \pm 1.16 \mu \mathrm{g} / \mathrm{L} \mathrm{As}$, $6.52 \pm 0.91 \mu \mathrm{g} / \mathrm{L} \mathrm{Hg}$, and $1.71 \pm 0.15 \mu \mathrm{g} / \mathrm{L} \mathrm{Pb}$ (Table 1). Cu and $\mathrm{Cr}$ had the highest mean concentration and $\mathrm{Pb}$ had the lowest mean concentration, the average metals concentration in the region was as follows: $\mathrm{Cu}>\mathrm{Cr}>\mathrm{Co}>\mathrm{As}>\mathrm{Hg}>\mathrm{Pb}$. Like this study, high concentration of $\mathrm{Cu}$ has been observed in other studies due to anthropogenic activities(Gimeno-García, Andreu et al. 1996, Akindele, Omisakin et al. 2020). The highest concentration of $\mathrm{Cu}, \mathrm{Co}$ and $\mathrm{As}$ was observed in Chapaqli station, $\mathrm{Hg}$ and $\mathrm{Pb}$ in Esmailsay and $\mathrm{Cr}$ in QalehPayan station, and the lowest concentration of metals was observed in Galugah. In the same area, Abadi et al.(2018) observed higher levels of $\mathrm{Hg}$ and $\mathrm{Pb}$ and lower levels of $\mathrm{Co}$, $\mathrm{Cu}$ and $\mathrm{As}$ in southern Caspian sea coasts than those observed in this study. Concentration of $\mathrm{Co}, \mathrm{Cu}, \mathrm{Pb}$, and As in water was higher in this study than those in the results of other researches.(Humbatov, Ahmadov et al. 2015, Fan,Chen et al. 2020, Pandiyan, Mahboob et al.2021). However, only the concentration of $\mathrm{Hg}$ was higher than the standard value set by WHO and USEPA, and the concentration of $\mathrm{Cr}$ was close to the standard value of WHO (Table 2). 
Table 1

Concentration of heavy metals in water and sediments at different stations

\begin{tabular}{|lllllllllllll|l|}
\hline \multicolumn{4}{|c}{ Water $(\boldsymbol{\mu g} / \mathbf{l})$} & \multicolumn{1}{c}{ Sediment $(\boldsymbol{\mu g} / \mathbf{g}$ dry weight $)$} \\
\hline Station & $\mathrm{Cr}$ & $\mathrm{Co}$ & $\mathrm{Cu}$ & $\mathrm{As}$ & $\mathrm{Hg}$ & $\mathrm{Pb}$ & $\mathrm{Cr}$ & $\mathrm{Co}$ & $\mathrm{Cu}$ & $\mathrm{As}$ & $\mathrm{Hg}$ & $\mathrm{Pb}$ \\
S1 & 80.91 & 4.08 & 93.35 & 7.75 & 14.85 & 1.61 & 3.7 & 1.28 & 2.9 & 4.2 & 7.4 & 7.4 \\
S2 & 61.15 & 8.45 & 27.08 & 6.47 & 6.29 & 1 & 4 & 1.43 & 4.5 & 6 & 17.7 & 11.7 \\
S3 & 2.2 & 2.73 & 1.58 & 5.25 & 3.04 & 1.45 & 3.6 & 1.63 & 3.7 & 4.8 & 7.7 & 9.3 \\
\hline S4 & 112.6 & 3.55 & 62.45 & 11.33 & 3 & 1.19 & 3.2 & 1.28 & 3.2 & 6.4 & 51.2 & 8.9 \\
\hline S5 & 49.94 & 8.41 & 52.1 & 6.29 & 15.87 & 3.12 & 3.5 & 1.29 & 2.7 & 1.5 & 7.3 & 9 \\
\hline S6 & 35.24 & 9.59 & 16.73 & 5.56 & 6.5 & 2.94 & 2.8 & 1 & 2 & 2 & 6.8 & 4.5 \\
\hline S7 & 35.18 & 11.4 & 19.8 & 4.86 & 2.41 & 0.76 & 3 & 1 & 2.5 & 2.9 & 629 & 7.2 \\
\hline S8 & 20.8 & 36 & 205.3 & 26.67 & 4.96 & 1.83 & 3.4 & 1.2 & 2.6 & 4.9 & 6.6 & 6.5 \\
\hline S9 & 31.82 & 5.36 & 197 & 7.32 & 1.67 & 1.64 & 2.7 & 0.9 & 2.1 & 3.3 & 8.8 & 7.7 \\
\hline S10 & 14.49 & 10.7 & 14.9 & 6.42 & 6.56 & 1.62 & 2.9 & 0.86 & 10 & 6.9 & 390 & 7.7 \\
\hline Mean & 44.56 & 10 & 69.03 & 8.79 & 6.52 & 1.71 & 3.2 & 1.2 & 3.6 & 4.3 & 113 & 8 \\
\hline
\end{tabular}


Table 2

Comparison of heavy metal concentration with different standards and other literature

\begin{tabular}{|c|c|c|c|c|c|c|c|c|}
\hline Location & & $\mathrm{Cr}$ & Co & $\mathrm{Cu}$ & As & $\mathrm{Hg}$ & $\mathrm{Pb}$ & References \\
\hline \multirow{2}{*}{$\begin{array}{l}\text { southeastern } \\
\text { Caspian Sea }\end{array}$} & Water( $\mu \mathrm{g} / \mathrm{l})$ & 44.56 & 10 & 69.03 & 8.79 & 6.52 & 1.71 & \multirow[t]{2}{*}{ This study } \\
\hline & $\begin{array}{l}\text { Sediment } \\
(\mu \mathrm{g} / \mathrm{g})\end{array}$ & 3.2 & 1.2 & 3.6 & 4.3 & 113 & 8 & \\
\hline \multirow[t]{2}{*}{ WPV a } & WHO & 50 & & 3000 & 10 & 1 & 10 & (WHO 2017) \\
\hline & USEPA & 100 & & 1000 & 10 & 2 & 15 & (USEPA 2017) \\
\hline \multirow[t]{4}{*}{$\mathrm{SQG}_{\mathrm{S}}{ }^{\mathrm{b}}$} & $\mathrm{TEL}^{\mathrm{c}}$ & 42.3 & & 124 & 7.24 & 0.13 & 30.2 & (CCME 1999) \\
\hline & PEL d & 160 & & 271 & 41.6 & 0.7 & 112 & \\
\hline & $\mathrm{ERL}^{\mathrm{e}}$ & 81 & & 150 & 8.2 & 0.15 & 46.7 & \multirow[t]{2}{*}{ (NOAA 2012) } \\
\hline & ERM $^{f}$ & 370 & & 410 & 70 & 0.71 & 218 & \\
\hline Caspian Sea & Water & & 1.06 & 5.53 & 1.26 & 1.42 & 1.92 & $\begin{array}{l}\text { (Abadi, Zamani } \\
\text { et al. 2018) }\end{array}$ \\
\hline Caspian Sea & Water & & 0.04 & 0.81 & 1.51 & & 0.24 & $\begin{array}{l}\text { (Humbatov, } \\
\text { Ahmadov et al. } \\
\text { 2015) }\end{array}$ \\
\hline $\begin{array}{l}\text { South } \\
\text { Caspian Sea }\end{array}$ & $\begin{array}{l}\text { Sediment } \\
\text { (winter) }\end{array}$ & & & 8.1 & 2.6 & & 10.6 & $\begin{array}{l}\text { (Ghorbanzadeh } \\
\text { Zaferani, } \\
\text { Machinchian } \\
\text { Moradi et al. } \\
\text { 2016) }\end{array}$ \\
\hline $\begin{array}{l}\text { Southern } \\
\text { Caspian Sea }\end{array}$ & Sediment & & 15 & 19 & 11 & & 13 & $\begin{array}{l}\text { (Agah, } \\
\text { Hashtroodi et } \\
\text { al. 2011) }\end{array}$ \\
\hline $\begin{array}{l}\text { South } \\
\text { Caspian Sea }\end{array}$ & Sediment & 95 & 16.3 & 31 & & & 20 & $\begin{array}{l}\text { (Alizadeh Ketek } \\
\text { Lahijani, } \\
\text { Naderi Beni et } \\
\text { al. 2018) }\end{array}$ \\
\hline \multirow{2}{*}{$\begin{array}{l}\text { Sheyang } \\
\text { River }\end{array}$} & Water & - & & 3.12 & 1.83 & 0.025 & 0.55 & \multirow{2}{*}{$\begin{array}{l}\text { (Zhao, Xu et al. } \\
\text { 2018) }\end{array}$} \\
\hline & Sediment & 37.19 & & 23.51 & 12.85 & 0.020 & 16.87 & \\
\hline \multirow[t]{2}{*}{ Yangtze River } & Water & 0.279 & & 1.47 & 1.94 & 36.3 & 0.829 & \multirow{2}{*}{$\begin{array}{l}\text { (Fan, Chen et } \\
\text { al. 2020) }\end{array}$} \\
\hline & sediment & 34.4 & & 19.7 & 8.80 & 0.065 & 25.8 & \\
\hline \multirow{2}{*}{$\begin{array}{l}\text { Point } \\
\text { Calimere } \\
\text { Wildlife } \\
\text { Sanctuary }\end{array}$} & Water & 2.9 & 0.4 & 0.1 & & 1.5 & 1.4 & \multirow{2}{*}{$\begin{array}{l}\text { (Pandiyan, } \\
\text { Mahboob et al. } \\
\text { 2021) }\end{array}$} \\
\hline & sediment & 0.8 & 1.8 & 0.3 & & 26 & 2.5 & \\
\hline
\end{tabular}




\begin{tabular}{|c|c|c|c|c|c|c|c|c|}
\hline Location & & $\mathrm{Cr}$ & Co & $\mathrm{Cu}$ & As & $\mathrm{Hg}$ & $\mathrm{Pb}$ & References \\
\hline \multirow{2}{*}{$\begin{array}{l}\text { Shadegan } \\
\text { Wetland }\end{array}$} & Water & ND & ND & ND & ND & ND & 1.11 & \multirow{2}{*}{$\begin{array}{l}\text { (Ashayeri and } \\
\text { Keshavarzi } \\
\text { 2019) }\end{array}$} \\
\hline & sediment & 54.62 & 10.77 & 20.42 & 3.40 & 0.07 & 16.89 & \\
\hline \multicolumn{9}{|c|}{ a: Water Permissible Value; } \\
\hline \multicolumn{9}{|c|}{ b: Sediment Quality Guideline; } \\
\hline \multicolumn{9}{|c|}{ c: Threshold Effect Level; } \\
\hline \multicolumn{9}{|c|}{ d: Probable Effect Level; } \\
\hline \multicolumn{9}{|c|}{ e: Effect Range Low; } \\
\hline$f:$ Effect Ra & Medium. & & & & & & & \\
\hline
\end{tabular}

The overall mean concentration of the metals in the sediment was $3.2 \pm 0.16 \mu \mathrm{g} / \mathrm{g} \mathrm{Cr}, 1.2 \pm 0.07 \mu \mathrm{g} / \mathrm{g} \mathrm{Co}$, $3.6 \pm 0.66 \mu \mathrm{g} / \mathrm{g} \mathrm{Cu}, 4.3 \pm 0.46 \mu \mathrm{g} / \mathrm{g} \mathrm{As}, 113 \pm 70.54 \mu \mathrm{g} / \mathrm{g} \mathrm{Hg}$, and $8 \pm 0.60 \mu \mathrm{g} / \mathrm{g} \mathrm{Pb}$ (Table 1). Unlike water samples, $\mathrm{Hg}$ and $\mathrm{Pb}$ had the highest concentration in sediment samples, and Co had the lowest concentration; the concentration sequence of heavy metals in sediment samples was as follows: $\mathrm{Hg}>\mathrm{Pb}$ $>\mathrm{As}>\mathrm{Cu}>\mathrm{Cr}>\mathrm{Co}$. The highest concentration of $\mathrm{Co}, \mathrm{Cr}$ and $\mathrm{Pb}$ was observed in Miankaleh center, whereas the highest concentration of $\mathrm{Cu}, \mathrm{As}$ and $\mathrm{Hg}$ was perceived in Ashouradeh station .Lahijani et al.(2018)and Agah et al. (2011)showed lower $\mathrm{Cr}$, As, $\mathrm{Cu}$ and $\mathrm{Pb}$ sediment concentration in Southern Caspian Sea than the levels obtained in this study. $\mathrm{Cr}, \mathrm{Cu}$, and $\mathrm{Pb}$ sediment concentration observed in this study is lower than the values obtained in Yangtze River (Fan, Chen et al. 2020); however, higher concentration of these metals was observed in Point Calimere Wildlife Sanctuary(Pandiyan, Mahboob et al. 2021).Only Hg concentration was higher than the permissible standards set by Canadian sediment quality guidelines for the protection of aquatic life and National Oceanic and Atmospheric Administration, so it was approximately 160 times higher than PEL and ERM values and 560 times higher than TEL and ERL values (Table 2).Existence of agricultural lands and using fertilizers and pesticides by farmers can be some of the main reasons for the accumulation of $\mathrm{Pb}$ and $\mathrm{Hg}$ in sediments (Hashmi, Malik et al. 2013, Pandiyan, Mahboob et al. 2021). A comparison between the heavy metal concentration in this study with the other similar studies is presented in Table 2. A similar result was obtained in the study of water and sediment samples of The Point Calimere Wildlife Sanctuary by Pandiyan et al.(2021);the highest concentration of $\mathrm{Cr}$ was in water samples and the highest concentration of $\mathrm{Hg}$ and $\mathrm{Pb}$ was observed in sediment samples. In addition, high concentration of $\mathrm{Hg}$ and $\mathrm{Pb}$ in sediment samples and high concentration of $\mathrm{Cu}$ in water samples in BS region were observed by Tian et al.(2020).

In order to identify and interpret the source of heavy metals more accurately, principal component analysis (PCA) and correlation analysis were used. A correlation matrix map of six heavy metals in water and sediments is demonstrated in Fig. 2. Relationships among metals in the surface water demonstrate significant positive correlations between $\mathrm{Co}$ and $\mathrm{Cu}(r=0.9, \mathrm{p}<0.000), \mathrm{Cu}$ and $\mathrm{As}(r=0.68, \mathrm{P}<0.000)$, and $\mathrm{Co}$ and $\mathrm{Pb}(\mathrm{r}=0.47, \mathrm{p}<0.03)$; besides, correlations between metals in the sediment display significant positive correlations between $\mathrm{Co}$ and $\mathrm{Cr}(\mathrm{r}=0.85, \mathrm{p}<0.002), \mathrm{Cr}$ and $\mathrm{Pb}(\mathrm{r}=0.68, \mathrm{P}=0.03), \mathrm{Cu}$ and $\mathrm{As}(\mathrm{r}=$ 
$0.66, p=0.03)$. Correlation of heavy metals has been observed in many studies in water and sediment samples (Islam, Das et al. 2020, Muhammad and Ahmad 2020).

PCA results showed that in water samples with eigen values $>1, \mathrm{Co}, \mathrm{As}$ and $\mathrm{Cu}$ are in the same group and were correlated with station eight. $\mathrm{Pb}$ and $\mathrm{Hg}$ are also in the same group and were correlated with the station number five. $\mathrm{Cr}$ did not form any clusters with other metals but was associated with the first station (Fig. 3). The first component ( $\mathrm{Co}$, As and $\mathrm{Cu}$ ) was $45 \%$, the second component ( $\mathrm{Pb}$ and $\mathrm{Hg}$ ) was $26 \%$, and the third variable $(\mathrm{Cr})$ included $19 \%$ of the component. PCA for water showed that three components had $90 \%$ of the variance. The main source of metals in PC1 could be municipal wastewater which entered the wetland without treatment. The source of $\mathrm{Pb}$ and $\mathrm{Hg}$ metals in the PC2 could also be human activities (agricultural activities and transportation). Many studies have shownthat $\mathrm{Pb}$ and $\mathrm{Hg}$ are the marker elements of atmospheric deposition, primarily due to the long-distance atmospheric transport of anthropogenic $\mathrm{Pb}$ and $\mathrm{Hg}$ (Chaturvedi et al., 2018; Chen et al., 2019; Lin et al., 2013; Xiao et al., 2017; Yamaguchi et al., 2003), In addition, agricultural effluents are other sources of these metals entry into aquatic environments (Xiao, Jian et al. 2017, Chaturvedi, Bhattacharjee et al. 2018, Chen, Liang et al. 2019). The PC3, which contained only $\mathrm{Cr}$, could be attributed to natural sources and geogenic sources. The natural origin of Cr has been observed in many studies (Micó, Recatalá et al. 2006, Xu, Wang et al. 2014, Deng, Yang et al. 2020, Lin, Li et al. 2020, Tian, Wu et al. 2020). In sediment, Cr, Co, and Pbwere in one group, and $\mathrm{Cu}$ and Aswere in the other group (Fig. 3). PC1 ( $\mathrm{Cr}$, Co and Pb) included 46\% and PC2 (Cu and As) included $32 \%$ of the variance. Principal component analysis for sediment showed that these two components included $0.78 \%$ of the variance. Heavy metal concentration in sediment was not only affected by the current concentration in the surface water but also caused changes in metal concentration owing to settling, accumulation, and binding (Schertzinger, Ruchter et al. 2018). Therefore, determining the source of the metal in the sediment is more complex than in water. Metals in PC2 were probably affected by human activities, especially municipal wastewater, while the origin of metals in PC1 could be both human due to agricultural and transportation activities (for $\mathrm{Pb}$ and $\mathrm{Co}$ ) and natural (for $\mathrm{Cr}$ ). Pearson correlation of $\mathrm{Cr}$ with $\mathrm{Co}$ and $\mathrm{Pb}$ as well as $\mathrm{As}$ and $\mathrm{Cu}$ in sediment and the high correlation of $\mathrm{Cu}$ with $\mathrm{Co}$ and As in water samples were consistent with PCA results for both sediment and water, indicating the common sources of each heavy metal group.

\section{Heavy Metals Concentration in fish species}

The concentration of heavy metals, $\mathrm{Cr}, \mathrm{Co}, \mathrm{Cu}, \mathrm{As}, \mathrm{Hg}$, and $\mathrm{Pb}$ in the liver, muscle, and skin of $\mathrm{C}$. carpio and L. auratus fish species demonstrates in Table 3. The distribution of the heavy metal concentration in the liver, muscle, and skin in $\mathrm{C}$. carpio was as follows: $\mathrm{Cu}>\mathrm{Pb}>\mathrm{Hg}>\mathrm{Cr}>\mathrm{As}>\mathrm{Co}, \mathrm{Pb}>\mathrm{Cu}>\mathrm{Hg}>\mathrm{Cr}>\mathrm{As}>\mathrm{Co}$ and $\mathrm{Cu}>\mathrm{Pb}>\mathrm{Hg}>\mathrm{As}>\mathrm{Cr}>\mathrm{Co}$, whereas in L. auratus, it was $\mathrm{Cu}>\mathrm{Pb}>\mathrm{As}>\mathrm{Hg}>\mathrm{Cr}>\mathrm{Co}, \mathrm{Cu}>\mathrm{Pb}>\mathrm{As}>\mathrm{Hg}>$ $\mathrm{Cr}>\mathrm{Co}$ and $\mathrm{Pb}>\mathrm{Cu}>\mathrm{As}>\mathrm{Cr}>\mathrm{Hg}>\mathrm{Co}$ respectively. $\mathrm{Cu}$ and $\mathrm{Pb}$ had the highest concentration, and $\mathrm{Co}$ had the lowest concentration in liver, muscle, and skin tissues in both fish species. High levels of $\mathrm{Cu}$ and $\mathrm{Pb}$ compared to other heavy metals in different species of fish were observed in Cauvery delta region, India by Dhanakumar et al.(2015). Regarding the analysis of the elements between the different species for each tissue, no significant differences for all metals was observed in the muscle of fish species. The concentration of $\mathrm{Hg}$ and $\mathrm{Pb}$ showed no significant differences in the liver and skin of fish species, while 
$\mathrm{Cr}, \mathrm{Co}, \mathrm{Cu}$, and $\mathrm{As}$ in the liver and $\mathrm{Cu}$ in the skin were significantly different. Liver was the tissue which accumulated these elements in $C$. carpio and $L$. auratus except for As and $\mathrm{Cr}$ in $C$. carpio; furthermore, metals in $L$. auratus liver were more than $C$. carpio liver except for $\mathrm{Hg} . \mathrm{Cr}, \mathrm{Hg}$ and $\mathrm{Pb}$ which were accumulated in $C$. carpio muscle more than $L$. auratus muscle, while $\mathrm{Co}, \mathrm{Cu}$, and $\mathrm{As}$ were most accumulated in the $L$. auratus muscle. Additionally, metals were accumulated in $C$. carpio skin more than L. auratus skin except for $\mathrm{Pb}$. Metallothionein protein content and metabolic activity of the liver lead to higher accumulation of heavy metals in the liver tissue than other fish organs (Kargın and Çoğun 1999, Çoğun, Yüzereroğlu et al. 2005, Nabavi, Nabavi et al. 2012); in addition, the liver acts as a filter to detoxify metals, which leads to higher accumulation of metals (Jezierska and Witeska 2006). In this study, as in other studies, the concentration of heavy metals in the liver was higher than other organs (Yılmaz, Özdemir et al. 2007, Keshavarzi, Hassanaghaei et al. 2018, Aytekin, Kargın et al. 2019). In general, the concentration of heavy metals in the muscle was less compared to the liver. fish muscles are the main edible parts, But they are not the tissue in which heavy metals are accumulated. Low concentration of heavy metals in muscle relative to other organs has also been shown in other studies (Yılmaz, Özdemir et al. 2007, Rajeshkumar and Li 2018, Aytekin, Kargın et al. 2019). Maurya et al.(2019) showed that heavy metals concentration in the seven species of fish studied in River Ganga basin was as follows: liver > gill > muscle. Also, the trend of heavy metals concentration in different species of fish was as follows: $\mathrm{Zn}>\mathrm{Cu}$ $>\mathrm{Pb}>\mathrm{Cd}>\mathrm{Cr}$. The results of ANOVA test in the C.carpio species showed that there was a considerable difference between the amount of $\mathrm{Cr}$ and As in liver and skin tissues. In addition, a significant difference was observed between liver and muscle in relation to Co and As. In the case of $L$. auratus species, significant difference was clear between liver and skin for $\mathrm{Co}, \mathrm{Cu}, \mathrm{As}$, and $\mathrm{Hg}$ metals. Furthermore, liver and skin had remarkable differences in terms of $\mathrm{Co}$, $\mathrm{Cu}$, and As metals (Fig. 4). Rajeshkumar et al.(2018) showed that the concentration of heavy metals in the liver of C.carpio was as follows, $\mathrm{Pb}>\mathrm{Cu}>\mathrm{Cr}>\mathrm{Cd}$; also, higher concentration in liver than muscle and a significant difference in the concentration of heavy metals in different tissues of $P$. fluvidraco and $C$. carpio species was observed. The results of this study were somewhat similar to the results of our study. As it can be seen in Table 4, mean values of $\mathrm{Pb}, \mathrm{Hg}, \mathrm{As}$, and $\mathrm{Cu}$ were above the recommended limits of $\mathrm{FAO} / \mathrm{WHO} / \mathrm{EU}$ in muscle tissue of C.carpio and L.auratus. Although, mean $\mathrm{Cu}$ in muscle tissue of $C$.carpio and L.auratus was higher than the amount suggested by WHOIEU, the levels of $\mathrm{Cu}$ in muscle tissue of $C$.carpio were very close to FAO recommended value. Moreover, while $\mathrm{Cr}$ value in muscle tissue of $C$. carpio and $L$. auratus exceeded the maximum limit recommended by EU, $\mathrm{Cr}$ mean value in muscle tissue of $C$. carpio and $L$. auratus was below the upper limits given by WHO. The heavy metal levels measured for muscles of the two fish species from Miankaleh wetland in this study and in other literatures are represented in Table 4. Heavy metals concentration in the existing literatures indicated that metal contents in the fish muscles vary depending on where and which species were caught. Even the average of the two fish species studied in the same area in other studies showed lower and higher values than the obtained values. 
Table 3

Mean metal concentration $(\mu \mathrm{g} / \mathrm{g})$ in the liver, muscles, skin of two fish species

\begin{tabular}{|c|c|c|c|c|c|c|c|}
\hline organ & species & $\mathrm{Cr}$ & Co & $\mathrm{Cu}$ & As & $\mathrm{Hg}$ & $\mathrm{Pb}$ \\
\hline \multirow[t]{2}{*}{ liver } & C. carpio & $\begin{array}{l}3.65 \pm \\
1.03^{\mathrm{a}}\end{array}$ & $\begin{array}{l}1.2 \pm \\
0.34^{\mathrm{a}}\end{array}$ & $27 \pm 7.50^{a}$ & $2 \pm 0.3^{a}$ & $\begin{array}{l}17.4 \pm \\
5.64\end{array}$ & $18.9 \pm 4.19$ \\
\hline & $\begin{array}{l}\text { L. } \\
\text { auratus }\end{array}$ & $\begin{array}{l}7.35 \pm \\
1.41^{\mathrm{b}}\end{array}$ & $\begin{array}{l}5.4 \pm \\
1.49^{b}\end{array}$ & $\begin{array}{l}1414 \pm \\
629^{b}\end{array}$ & $\begin{array}{l}28.2 \pm \\
7.1^{\mathrm{b}}\end{array}$ & $\begin{array}{l}11.1 \pm \\
3.41\end{array}$ & $31.7 \pm 1.19$ \\
\hline \multirow[t]{2}{*}{ muscle } & C. carpio & $5.5 \pm 1.44$ & $0.2 \pm 0.02$ & $10 \pm 1.11$ & $4 \pm 0.74$ & $9.3 \pm 2.02$ & $18.8 \pm 5.03$ \\
\hline & $\begin{array}{l}\text { L. } \\
\text { auratus }\end{array}$ & $4 \pm 0.96$ & $\begin{array}{l}0.29 \pm \\
0.07\end{array}$ & $\begin{array}{l}37.2 \pm \\
17.3\end{array}$ & $5.8 \pm 1.2$ & $\begin{array}{l}4.98 \pm \\
1.89\end{array}$ & $8.27 \pm 3.61$ \\
\hline \multirow[t]{2}{*}{ skin } & C. carpio & $\begin{array}{l}8.87 \pm \\
1.67\end{array}$ & $1.1 \pm 0.32$ & $\begin{array}{l}26.4 \pm \\
4.85^{\mathrm{a}}\end{array}$ & $\begin{array}{l}9.17 \pm \\
1.92\end{array}$ & $\begin{array}{l}5.02 \pm \\
2.39\end{array}$ & $9.9 \pm 4.57$ \\
\hline & $\begin{array}{l}\text { L. } \\
\text { auratus }\end{array}$ & $\begin{array}{l}5.72 \pm \\
1.66\end{array}$ & $0.8 \pm 0.32$ & $\begin{array}{l}10.8 \pm \\
2.29^{b}\end{array}$ & $\begin{array}{l}5.98 \pm \\
1.15\end{array}$ & $1.7 \pm 0.57$ & $\begin{array}{l}11.74 \pm \\
5.27\end{array}$ \\
\hline
\end{tabular}


Table 4

Comparison of heavy metal concentration in the muscles of two examined fish with different standards and other literature

\begin{tabular}{|c|c|c|c|c|c|c|c|c|}
\hline & & $\mathrm{Cr}$ & Co & $\mathrm{Cu}$ & As & $\mathrm{Hg}$ & $\mathrm{Pb}$ & References \\
\hline $\mathrm{WHO}^{\mathrm{a}}$ & & 50 & & 30 & & & 2 & (WHO 1989) \\
\hline $\mathrm{FAO}^{\mathrm{b}}$ & & & & 10 & & & 0.5 & (FAO 1983) \\
\hline $\mathrm{EU}^{\mathrm{c}}$ & & 0.15 & & 30 & 0.1 & 0.5 & 0.5 & $\begin{array}{l}\text { (GB2762 } \\
\text { 2017) }\end{array}$ \\
\hline \multirow[t]{2}{*}{$\begin{array}{l}\text { southeastern } \\
\text { Caspian Sea }\end{array}$} & $\begin{array}{l}\text { C. } \\
\text { carpio }\end{array}$ & 5.5 & 0.2 & 10 & 4 & 9.3 & 18.8 & \multirow[t]{2}{*}{ This study } \\
\hline & $\begin{array}{l}\text { L. } \\
\text { auratus }\end{array}$ & 4 & 0.29 & 37.2 & 5.8 & 4.98 & 8.27 & \\
\hline \multirow[t]{2}{*}{ Gorgan Bay } & $\begin{array}{l}\text { C. } \\
\text { carpio }\end{array}$ & 6.4 & & & & & 0.43 & \multirow{2}{*}{$\begin{array}{l}\text { (Alipour and } \\
\text { Banagar } \\
\text { 2018) }\end{array}$} \\
\hline & $\begin{array}{l}\text { L. } \\
\text { auratus }\end{array}$ & 0.93 & & & & & 8.6 & \\
\hline Beyşehir Lake & $\begin{array}{l}\text { C. } \\
\text { carpio }\end{array}$ & 12.11 & & & & & 2.84 & $\begin{array}{l}\text { (Özparlak, } \\
\text { Arslan et al. } \\
\text { 2012) }\end{array}$ \\
\hline \multirow[t]{2}{*}{ Caspian Sea } & $\begin{array}{l}\text { C. } \\
\text { carpio }\end{array}$ & 74.6 & & & & & 139.9 & \multirow[t]{2}{*}{$\begin{array}{l}\text { (Saravi, } \\
\text { Karami et al. } \\
\text { 2012) }\end{array}$} \\
\hline & $\begin{array}{l}\text { M. } \\
\text { auratus }\end{array}$ & 31.27 & & & & & 77.67 & \\
\hline \multirow[t]{2}{*}{ Caspian Sea } & $\begin{array}{l}\text { C. } \\
\text { carpio }\end{array}$ & 37.82 & & & & & 139.3 & \multirow{2}{*}{$\begin{array}{l}\text { (Tabari, } \\
\text { Saravi et al. } \\
\text { 2010) }\end{array}$} \\
\hline & $\begin{array}{l}\text { M. } \\
\text { auratus }\end{array}$ & 83.95 & & & & & 75.12 & \\
\hline Caspian Sea & $\begin{array}{l}\text { C. } \\
\text { carpio }\end{array}$ & & 0.92 & 4.41 & & & 0.77 & $\begin{array}{l}\text { (Solgi, } \\
\text { Alipour et al. } \\
\text { 2018) }\end{array}$ \\
\hline \multirow[t]{2}{*}{ Tigris River } & $\begin{array}{l}\text { C. } \\
\text { regium }\end{array}$ & 1.05 & 0.04 & 0.05 & 0.02 & & 0.11 & \multirow{2}{*}{$\begin{array}{l}\text { (Töre, } \\
\text { Ustaoğlu et } \\
\text { al. 2021) }\end{array}$} \\
\hline & C. trutta & 1.14 & 0.03 & 0.77 & 0.25 & & 0.19 & \\
\hline
\end{tabular}
a: World Health Organization
b: Food and Agriculture Organization
c: European Union 


\begin{tabular}{|lccccccc|}
\hline & Cr & Co & Cu & As & Hg & Pb & References \\
\hline $\begin{array}{l}\text { Liuzhou } \\
\text { wild } \\
\text { fish }\end{array}$ & 0.796 & & 0.656 & 0.028 & 0.012 & 0.009 & $\begin{array}{l}\text { (Miao, Hao et } \\
\text { al. 2021) }\end{array}$ \\
\hline a: World Health Organization & & & & & & & \\
\hline b: Food and Agriculture Organization & & & & & & \\
\hline c: European Union & & & & & & & \\
\hline
\end{tabular}

\section{Human Health risks posed by heavy metals in fish species}

Heavy metals level in the muscle of the two fish species was used to assess health risk by EDI, THQ and CR values (Sharafi, Nodehi et al. 2019, Abd-Elghany, Zaher et al. 2020). Figure 5 provides the estimated THQ for each heavy metal from the two fish species consumption. The estimated target hazard quotients (THQ) for metals were reduced for $C$. carpio and $L$. Auratus species respectively: $\mathrm{Hg}>\mathrm{As}>\mathrm{Pb}>\mathrm{Cr}>\mathrm{Cu}>$ $\mathrm{Co}$, and $\mathrm{Hg}>\mathrm{As}>\mathrm{Cr}>\mathrm{Pb}>\mathrm{Cu}>\mathrm{Co}$. For all metals, $\mathrm{THQ}$ values were less than 1. This indicated that people would not encounter significant non-carcinogenic health risks from the ingestion of metals through fish consumption. The lowest THQ value for the two species was perceived for $\mathrm{Co}(2.6 \mathrm{E}-06$ and $4.1 \mathrm{E}-06$ for $C$. carpio and $L$. auratus respectively), while the highest mean THQ value was for $\mathrm{Hg}$ (4E-02 and 2.1E-02 for $C$. carpio and $L$. auratus respectively), which still demonstrates no potential health risk. The two species under the current study were found invulnerable for consumption, however, if people are exposed to more than one heavy metal at the same time, they can encounter blended or interactive effects (Loaiza, De Troch et al. 2018). Therefore, the TTHQ was evaluated to find out the additive effects of various heavy metals on human body. Our results demonstrated that the combined impact of all heavy metal levels was still lower than the acceptable limit of 1 for TTHQ (Fig. 5), but consumption of $C$. carpio has a higher risk than L. auratus (4.9E-02 versus 3.1E-02).

$\mathrm{EDI}$ of $\mathrm{Pb}, \mathrm{Cd}, \mathrm{Cr}, \mathrm{As}$, and $\mathrm{Hg}$ through the consumption of $C$. carpio and $L$. auratus fish species was summarized in Table 5. EDI values were compared with the respectively recommended daily dietary allowance of each individual metal proposed by several references, such as Joint FAO/WHO Expert Committee on Food Additive (JECFA) As, Cu, and Pb (JECFA,1982, 1989, 2000), World Health Organization (WHO) for Co (WHO, 1996, 2006), and National Research Council (NRC) for Cr (NRC, 1989). It was found that EDI results for all metals were less than the recommended levels, indicating that there is no risk to human health in relation to the consumption of heavy metals studied through the consumption of the selected fish species. The results depicted that the lowest value of EDI was perceived for Co through the utilization of the two selected fish species (7.71E-05 and 8.29E-05 for C. carpio and L. auratus respectively), while the highest was for $\mathrm{Cu}$ in $L$. auratus(1.06E-02) and $\mathrm{Pb}$ in $C$. carpio(5.38E-03). 
Table 5

Calculated estimated daily intake and cancer risk for each heavy metal in fish species

\begin{tabular}{|c|c|c|c|c|c|}
\hline metals & species & $\begin{array}{l}\text { EDI }^{a} \\
\text { (mg/day/person) }\end{array}$ & $\begin{array}{l}\text { Recommended daily dietary } \\
\text { (mg/day/person) }\end{array}$ & $\mathrm{CFS}^{\mathrm{b}}$ & $\mathrm{CR}^{\mathrm{c}}$ \\
\hline \multirow[t]{2}{*}{$\mathrm{Cr}$} & C. carpio & $2.35 \mathrm{E}-03$ & \multirow{2}{*}{$0.20^{\mathrm{e}}$} & 0.050 & $1.17 \mathrm{E}-03$ \\
\hline & L. auratus & $1.73 \mathrm{E}-03$ & & 0.050 & $8.66 \mathrm{E}-04$ \\
\hline \multirow[t]{2}{*}{ Co } & C. carpio & 7.71E-05 & & & \\
\hline & L. auratus & $8.29 \mathrm{E}-05$ & & & \\
\hline \multirow[t]{2}{*}{$\mathrm{Cu}$} & C. carpio & $2.86 \mathrm{E}-03$ & & & \\
\hline & L. auratus & $1.06 \mathrm{E}-02$ & & & \\
\hline \multirow[t]{2}{*}{ As } & C. carpio & $1.14 \mathrm{E}-03$ & \multirow[t]{2}{*}{$0.13^{d}$} & 1.50 & $2.58 \mathrm{E}-03$ \\
\hline & L. auratus & 1.67E-03 & & 1.50 & 3.77E-03 \\
\hline \multirow[t]{2}{*}{$\mathrm{Hg}$} & C. carpio & $2.67 \mathrm{E}-03$ & \multirow[t]{2}{*}{$0.03^{d}$} & & \\
\hline & L. auratus & $1.42 \mathrm{E}-03$ & & & \\
\hline \multirow[t]{2}{*}{$\mathrm{Pb}$} & C. carpio & $5.38 \mathrm{E}-03$ & \multirow[t]{2}{*}{$0.21^{d}$} & 0.0085 & $6.86 \mathrm{E}-05$ \\
\hline & L. auratus & $2.36 \mathrm{E}-03$ & & 0.0085 & $3.014 \mathrm{E}-05$ \\
\hline \multicolumn{6}{|c|}{ a: Estimated Daily Intake } \\
\hline \multicolumn{6}{|c|}{ b: Cancer Slope Factor } \\
\hline \multicolumn{6}{|c|}{ c: Cancer Risk } \\
\hline \multicolumn{6}{|c|}{ d: (JECFA, 2009) Evaluations of the Joint FAO/WHO Expert Committee on Food Additives } \\
\hline \multicolumn{6}{|c|}{ e: (RDA, 1989) } \\
\hline
\end{tabular}

It is noteworthy that exposure to heavy metals is correlated with wide spectrum carcinogenesis and can damage the nervous system seriously); therefore, CR index was estimated by the use of CFS values for Cr, $\mathrm{As}$, and $\mathrm{Pb}$ in two species. In our study, $\mathrm{CR}$ for As and $\mathrm{Cr}$ in two species were higher than the intolerable range representing the risk of cancer due to exposure to $\mathrm{Cd}, \mathrm{Cr}$ and, As through fish consumption. The $\mathrm{CR}$ values due to the consumption of different metals through C. carpio and L. auratus is As $(2.58 \mathrm{E}-03)>\mathrm{Cr}$ (1.17E-03) > Pb (6.86E-05) and As (3.77E-03) > Cr (8.66E-04) > Pb (3.014E-05) respectively. Exposure to As because of the consumption of $\mathrm{C}$. carpio could cause higher risk for consumers.

\section{Biological monitoring of heavy metals in Turkmen pregnant women's different tissues}

Heavy metals concentration in Turkmen pregnant women's blood, fingernail, toenail and hair, considering their place of residence, fishermen families, age and number of dental amalgam fillings is represented in Table 6.Considering the mean heavy metal contents in different organs, higher $\mathrm{Cr}$, $\mathrm{Co}, \mathrm{Cu}, \mathrm{As}$, and $\mathrm{Hg}$ 
content were found at fingernail and the highest $\mathrm{Pb}$ content was observed at toenail, while the lowest concentration of heavy metals was observed in the blood. Copper had the highest concentration among the studied elements in blood, fingernail, toenail and hair, whereas Co concentration was observed to be lower in all organs. 
Heavy metals concentration in Turkmen pregnant women based on results from the questionnaire

\begin{tabular}{|c|c|c|c|c|c|c|c|c|c|}
\hline Organs & Characteristic & & $\mathbf{N}$ & $\mathrm{Cr}$ & Co & $\mathrm{Cu}$ & As & $\mathrm{Hg}$ & $\mathrm{Pb}$ \\
\hline \multirow{8}{*}{$\begin{array}{l}\text { Blood } \\
(\mathrm{mg} / \mathrm{l})\end{array}$} & \multirow{2}{*}{$\begin{array}{l}\text { Place of } \\
\text { residence }\end{array}$} & Qaraesou & 8 & 0.65 & 0.008 & 2.01 & 0.2 & 1.04 & 1.01 \\
\hline & & Chapaqli & 8 & 0.16 & 0.02 & 3.05 & 0.3 & 1.06 & 1.35 \\
\hline & \multirow{2}{*}{$\begin{array}{l}\text { Fishermen } \\
\text { families }\end{array}$} & Yes & 9 & 0.09 & 0.02 & 2.62 & 0.26 & 1.38 & $1.51 \mathrm{a}$ \\
\hline & & No & 7 & 0.16 & 0.01 & 2.38 & 0.24 & 0.5 & $0.63 b$ \\
\hline & \multirow{2}{*}{$\begin{array}{l}\text { dental } \\
\text { amalgam }\end{array}$} & Yes & 8 & 0.07 & 0.01 & 2.06 & 0.2 & 0.74 & 1.04 \\
\hline & & No & 8 & 0.16 & 0.01 & 3 & 0.3 & 1.35 & 1.33 \\
\hline & \multirow[t]{2}{*}{ Age } & $17-27$ & 9 & 0.07 & $0.009 a$ & 2.03 & 0.2 & 0.93 & 0.98 \\
\hline & & $27-37$ & 7 & 0.19 & $0.02 b$ & 3.37 & 0.34 & 1.23 & 1.53 \\
\hline Mean & & & 16 & 0.11 & 0.01 & 2.53 & 0.25 & 1.05 & 1.18 \\
\hline \multirow{8}{*}{$\begin{array}{l}\text { Fingernail } \\
(\mu \mathrm{g} / \mathrm{g})\end{array}$} & \multirow{2}{*}{$\begin{array}{l}\text { Place of } \\
\text { residence }\end{array}$} & Qaraesou & 8 & 16.8 & 1.45 & 42.2 & 3.19 & 6.26 & 6.25 \\
\hline & & Chapaqli & 8 & 17.3 & 1.14 & 30.7 & 2.81 & 5.85 & 7.01 \\
\hline & \multirow{2}{*}{$\begin{array}{l}\text { Fishermen } \\
\text { families }\end{array}$} & Yes & 9 & 15.45 & 1.28 & 39.9 & 3.32 & 5.49 & 6.87 \\
\hline & & No & 7 & 19.77 & 1.31 & 30.7 & 3.82 & 6.99 & 6.23 \\
\hline & \multirow{2}{*}{$\begin{array}{l}\text { dental } \\
\text { amalgam }\end{array}$} & Yes & 8 & 16 & 1.72 & 45 & 3.87 & 6.48 & $3.75 a$ \\
\hline & & No & 8 & 18 & 0.86 & 27.8 & 3.13 & 5.63 & $9.51 \mathrm{~b}$ \\
\hline & \multirow[t]{2}{*}{ Age } & $17-27$ & 9 & 16.28 & 1.27 & 38.6 & 2.84 & 6.33 & 5.37 \\
\hline & & $27-37$ & 7 & 18.38 & 1.33 & 32.8 & 4.6 & 5.59 & 8.77 \\
\hline Mean & & & 16 & 17.07 & 1.29 & 36.46 & 3.5 & 6.05 & 6.63 \\
\hline \multirow{8}{*}{$\begin{array}{l}\text { Toenail } \\
(\mu g / g)\end{array}$} & \multirow{2}{*}{$\begin{array}{l}\text { Place of } \\
\text { residence }\end{array}$} & Qaraesou & 8 & 7.03 & 0.19 & 28.9 & 3.28 & 4.12 & 19.1 \\
\hline & & Chapaqli & 8 & 11.64 & 0.39 & 29.1 & 2.69 & 2.82 & 14.04 \\
\hline & \multirow{2}{*}{$\begin{array}{l}\text { Fishermen } \\
\text { families }\end{array}$} & Yes & 9 & 5.65 & 0.28 & 25.7 & 3.5 & 3.98 & 16 \\
\hline & & No & 7 & 15.5 & 0.32 & 34.6 & 2.03 & 2.62 & 17.54 \\
\hline & \multirow{2}{*}{$\begin{array}{l}\text { dental } \\
\text { amalgam }\end{array}$} & Yes & 8 & 8.57 & 0.28 & $38.36 a$ & 3.68 & 4.45 & 20.76 \\
\hline & & No & 8 & 10.1 & 0.31 & $19.74 b$ & 2.29 & 2.49 & 12.4 \\
\hline & \multirow[t]{2}{*}{ Age } & $17-27$ & 9 & 7.55 & $0.19 a$ & 31.5 & 3.45 & 4.21 & 18.75 \\
\hline & & $27-37$ & 7 & 12.3 & $0.47 b$ & 24.9 & 2.2 & 2.24 & 12.97 \\
\hline Mean & & & 16 & 9.33 & 0.29 & & 2.98 & 3.47 & 16.58 \\
\hline
\end{tabular}




\begin{tabular}{|llllllllll|}
\hline Organs & Characteristic & & $\mathrm{N}$ & $\mathrm{Cr}$ & $\mathrm{Co}$ & $\mathrm{Cu}$ & $\mathrm{As}$ & $\mathrm{Hg}$ & $\mathrm{Pb}$ \\
\hline \multirow{3}{*}{$\begin{array}{l}\text { Hair } \\
(\mu \mathrm{g} / \mathrm{g})\end{array}$} & $\begin{array}{l}\text { Place of } \\
\text { residence }\end{array}$ & Qaraesou & 8 & 1.97 & 0.06 & 7.4 & 0.88 & 3.29 & 2.32 \\
& & Chapaqli & 8 & 1.8 & 0.12 & 10.32 & 1.33 & 1.42 & 2.49 \\
& $\begin{array}{l}\text { Fishermen } \\
\text { families }\end{array}$ & Yes & 9 & 1.74 & 0.07 & 8.58 & 1.17 & 2.8 & 2.34 \\
\cline { 2 - 9 } & No & 7 & 2.13 & 0.12 & 9.35 & 0.99 & 1.6 & 2.51 \\
& $\begin{array}{l}\text { dental } \\
\text { amalgam }\end{array}$ & Yes & 8 & 1.66 & 0.06 & 8.39 & 0.89 & 3 & 2.65 \\
\cline { 2 - 9 } & No & 8 & 2.12 & 0.12 & 9.36 & 1.32 & 1.72 & 2.15 \\
& Age & $17-27$ & 9 & 2.19 & 0.08 & 10.18 & 0.95 & 3.24 & 2.64 \\
\hline Mean & $27-37$ & 7 & 1.38 & 0.11 & 6.7 & 1.36 & 0.87 & 2 \\
\hline
\end{tabular}

The average concentration of $\mathrm{Cr}, \mathrm{Co}, \mathrm{Cu}, \mathrm{As}, \mathrm{Hg}$ and $\mathrm{Pb}$ metals in blood was 0.11 (0.02-0.3), 0.01 (0.006$0.02), 2.53$ (0.5-3.9), 0.25 (0.04-0.39), 1.05 (0.08-2.7), and $1.184(0.3-1.9) \mathrm{mg} / \mathrm{l}$ respectively. Although habitat did not have any significant effect on the accumulation of metals in blood, the average of all metals in Chapaqli was higher than Qaraesou except for $\mathrm{Cr}$. The mean concentration of blood heavy metals level was lower in non-fisherman families than in fisherman families except for $\mathrm{Cr}$, so the average concentration of $\mathrm{Pb}$ in fisherman families was significantly higher than non-fisherman families. As expected, fish is consumed in fishermen families more than non-fishermen families, so they are more likely to accumulate $\mathrm{Hg}$ in these people's body. Prokopowicz et al.(2014) showed that regular fish consumption 2-6 and more than 6 meals a month, increases the amount of $\mathrm{Hg}$ in blood by almost 2 and 3 times, respectively. Even small amounts of fish consumption can lead to $\mathrm{Hg}$ accumulation in blood (Jedrychowski, Jankowski et al. 2006, Ashrap, Watkins et al. 2020). It has also been found that increasing fish intake during pregnancy increases $\mathrm{Hg}$ in the mother's blood and cord blood (Davidson, Myers et al. 2004, Jeong, $\mathrm{Ha}$ et al. 2017). The average of the blood metals concentration increased slightly with age, but the effect of age was only significant for Cr metal. Wennberg et al.(2006)also showed as age went up, $\mathrm{Pb}$ and $\mathrm{Hg}$ concentration in blood increased, but this increase was not notable.

All the blood samples had higher concentration than the standard value for $\mathrm{Hg}$ set by USEPA $(5.8 \mu \mathrm{g} / \mathrm{L})$ (Council 2000) and WHO (10 $\mu \mathrm{g} / \mathrm{L})$ (UNIDO 2003).People who had their teeth filled had lower mean metal concentration ; therefore, dental amalgam did not display an association with heavy metal accumulation in blood, however, other studies have shown the effect of dental amalgam on mercury accumulation in blood(Mortada, Sobh et al. 2002, Prokopowicz, Pawlas et al. 2014). The measured levels of $\mathrm{Hg}$ and $\mathrm{Pb}$ in pregnant women's blood in this study were much higher than the levels of these metals in Korean female population (Lee, Lee et al. 2012), healthy women in their 50s in an urban area of Poland (Prokopowicz, Pawlas et al. 2014), nonsmokers volunteers in Saudi Arabia (Alrobaian and Arida 2019), women in Belgium (40-60 years) (Fierens, Rebolledo et al. 2016), Fez, Morocco, Guiyang, China, Wrocław, Poland, BanskaBystrica, Slovakia (Hrubá, Strömberg et al. 2012), only the amount of Cr was lower than the amount obtained for nonsmokers volunteers in Saudi Arabia (Alrobaian and Arida 2019). 
The mean concentration of $\mathrm{Cr}, \mathrm{Co}, \mathrm{Cu}, \mathrm{As}, \mathrm{Hg}$ and $\mathrm{Pb}$ metals in hair was 1.89 (0.78-3.09), 0.09 (0.02$0.26)$, 8.87 (1.76-21.21), 1.11 (0.54-1.76), 2.35 (0.15-4.47) and 2.40(0.5-3.93) $\mu \mathrm{g} / \mathrm{g}$ respectively. Place of residence, fishermen families, dental amalgam, and age had no significant effect on the concentration of heavy metals in hair. In addition, no specific trend was observed in the change of metals in relation to the mentioned factors. The concentration of As and $\mathrm{Hg}$ in the fishermen families was higher than the nonfishermen families like the results of Okati et al. (2018). As we reported the results of heavy metals concentration in water, sediment and two fish species, it was shown that the amount of Hg was higher than the specified standards, especially for sediment which was much higher than the permissible standards. It can be said that $\mathrm{Hg}$ accumulation in water and sediment has led to an increase in the concentration in fish species and consequently in the hair of pregnant women in the region. Marrugo et al. (2013) showed that although there was no significant difference between $\mathrm{Hg}$ concentration in relation to the number of days per week with fish consumption (NDWFC), number of meals per day with fish (NMDF), amount of fish consumption weekly (AFCW), a positive correlation between $\mathrm{Hg}$ concentration and the mentioned variables was obvious. In addition, the most important source of human exposure to $\mathrm{Hg}$ was polluted fish consumption. A significant positive correlations between the amount of fish consumption and $\mathrm{Hg}$ concentration in individuals' hair samples around Ayapel swamp, Colombia, was observed by Gracia et al. (2010). Other literatures have indicated that polluted fish is the main source of Hg exposure in communities which consume fish frequently(McDowell, Dillon et al. 2004, Al-Saleh 2020). Based on the guideline of USEPA reference dose $(1 \mu \mathrm{g} / \mathrm{g}$ in hair) (USEPA 2005) and WHO "normal" level $(2.0 \mu \mathrm{g} / \mathrm{g}$ in hair) for identifying the population at risk because of mercury exposure, when most of the hair samples exceed from the standard values, potential risks estimation for human health is necessary. In our study, $75 \%$ of the recorded hair samples were higher than the $\mathrm{Hg}$ references suggested by USEPA and WHO. This condition can be worrying and should be considered so as to avoid a potential public health crisis due to the polluted fish consumption in the study area. It can be seen that $\mathrm{Cr}, \mathrm{Cu}, \mathrm{As}$, and Pb levels (0.40-24.56 $\mu \mathrm{g} / \mathrm{g} \mathrm{dw}$ ) are higher than in non-liquor users aged between 20-40 (Abdulrahman, Akan et al. 2012)and lower than $\mathrm{Cr}, \mathrm{As}, \mathrm{Hg}$, and $\mathrm{Pb}$ concentration in nonsmokers volunteers (Alrobaian and Arida 2019). In addition, people with filled teeth showed higher levels of $\mathrm{Hg}$ and $\mathrm{Pb}$ metals; and in the first age group, the average concentration of $\mathrm{Pb}$ and $\mathrm{Hg}$ was higher. It can be concluded that the increase of age had no influence on metals levels in hair; this result has been obtained in other studies, as well (Okati and Esmaili-sari 2018).

The mean fingernail levels of $\mathrm{Cr}, \mathrm{Co}, \mathrm{Cu}, \mathrm{As}, \mathrm{Hg}$ and $\mathrm{Pb}$ were 17.07 (9.9-23.6), 1.29 (0.11-3.25), 36.46(19.9-54), 3.5(1.44-6.1), 6.05(4.39-7.54) and 6.63(1.63-14.21) $\mu \mathrm{g} / \mathrm{g}$ respectively; additionally, the average toenail levels of $\mathrm{Cr}, \mathrm{Co}, \mathrm{Cu}, \mathrm{As}, \mathrm{Hg}$, and Pb were 9.33 (1.57-29.6), 0.29 (0.09-0.67), 29.04 (9.2445.53), 2.98 (1.14-6.15), 3.47 (0.23-5.75) and 16.58 (1.28-23.31) $\mu \mathrm{g} / \mathrm{g}$ respectively. The mean concentration of all metals in fingernails was higher than toenails except for $\mathrm{Pb}$, also a significant difference was observed between the concentration of $\mathrm{Cr}, \mathrm{Co}, \mathrm{Hg}$, and $\mathrm{Pb}$ metals in toenails and fingernails. Abdulrahman et al.(2012) also observed notable differences in metal levels in fingernail and toenail in Maiduguri Metropolis, Borno State, Nigeria. Although higher concentration of metals in toenail than fingernail has been observed in a number of studies (Abdulrahman, Akan et al. 2012, Dessie, Melaku 
et al. 2020), higher concentration of $\mathrm{Cr}, \mathrm{Cu}$, and $\mathrm{Pb}$ metals in fingernail has also been seen in other researches (Przybylowicz, Chesy et al. 2012). Compared to hair samples, nail samples showed higher heavy metals accumulation; such differences might be related to the combination of elements with hair keratin structure, which happens by binding to sulfhydryl groups which are available in follicular protein. In this case detergents, such as soap, shampoos, hair pomades, lotions, hair bleaches and dyes can wash away heavy metals from the shaft bulk (Takagi, Matsuda et al. 1986, Abdulrahman, Akan et al. 2012, Koseoglu, Koseoglu et al. 2017). Comparing metals level in fingernail and toenail with various literatures showed that $\mathrm{Cr}, \mathrm{Co}, \mathrm{Cu}, \mathrm{As}, \mathrm{Hg}$, and $\mathrm{Pb}$ concentration in fingernail and toenail were generally higher than the results in other researches(Abdulrahman, Akan et al. 2012, Marrugo-Negrete, Ruiz-Guzmán et al. 2013, Al-Saleh 2020, Dessie, Melaku et al. 2020), however, mean Cr concentration in fingernail and toenail and Co in toenail were lower than the amount of metals in other literatures (Abdulrahman, Akan et al. 2012, Marrugo-Negrete, Ruiz-Guzmán et al. 2013, Al-Saleh 2020). The average concentration of $\mathrm{Cr}, \mathrm{Co}, \mathrm{Cu}$ and $\mathrm{Pb}$ in pregnant women's fingernail in this study were 9.4, 37.9, 4.8, and 6.6 times, and in the toenail were 5.3, $6.2,5.5$, and 14.4 times higher than the healthy women in Poland respectively(Przybylowicz, Chesy et al. 2012).Higher metals concentration can be caused by people's exposure to contaminated sources in the area, so there is a possibility for metals accumulation due to the contact with the contaminants in this area.

ANOVA was conducted to compare human organs,; the result indicated that there was no significant difference in relation to heavy metals seen in blood and hair, while a statistically significant difference was observed regarding the heavy metals $\mathrm{Cr}, \mathrm{Co}, \mathrm{Cu}, \mathrm{As}$, and $\mathrm{Hg}$ in hair and toenail and the $\mathrm{Cr}, \mathrm{Cu}, \mathrm{As}, \mathrm{Hg}$, and $\mathrm{Pb}$ in hair and fingernail. In addition, $\mathrm{Cr}, \mathrm{Co}, \mathrm{Hg}$, and $\mathrm{Pb}$ metals in toenail and fingernail were significantly different from $\mathrm{Cr}$, Co, As, and $\mathrm{Pb}$ metals in toenail and hair (Fig. 6).The correlation results of heavy metals in different samples demonstrated that there was a positive correlation between $\mathrm{Cr}, \mathrm{Co}, \mathrm{Cu}$, and $\mathrm{As}$ in blood samples and $\mathrm{Cr}$, $\mathrm{Co}$ and $\mathrm{Cu}$ metals in hair samples. In addition, positive correlations between $\mathrm{Co}$ and $\mathrm{As}$, as well as $\mathrm{Hg}$ and $\mathrm{Pb}$ were determined in fingernail and toenail samples respectively (Fig. 7)

\section{Conclusion}

According to the purpose of this study, the concentration of six heavy metals including cobalt, chromium, copper, arsenic, mercury, and lead in water and sediment samples as well as in muscle, skin and liver of $C$. carpio and $L$. auratus species were measured. In addition, for the first time, biological monitoring of heavy metals in the tissues of Turkmen pregnant women's blood, hair, fingernail, and toenail was performed. The results of metal measurements in water and sediment samples showed that $\mathrm{Cu}$ and $\mathrm{Cr}$ had the highest mean concentration and $\mathrm{Pb}$ had the lowest mean concentration in water samples, whereas in sediment samples, $\mathrm{Hg}$ and $\mathrm{Pb}$ had the highest concentration, and $\mathrm{Co}$ had the lowest one. The concentration of heavy metals in water and sediment samples was as follows: $\mathrm{Cu}>\mathrm{Cr}>\mathrm{Co}>\mathrm{As}>\mathrm{Hg}>\mathrm{Pb}$ for water, $\mathrm{Hg}>\mathrm{Pb}$ $>\mathrm{As}>\mathrm{Cu}>\mathrm{Cr}>\mathrm{Co}$ for sediment. Mean concentration of $\mathrm{Cr}, \mathrm{Co}, \mathrm{Cu}$, and $\mathrm{Pb}$ in the surface water and sediment was lower than the specified standards for water and sediment by various health organizations, while the concentration of $\mathrm{Hg}$ in the water and sediments exceeded the standard values. The average 
concentration of $\mathrm{Hg}$ in water was 6 times higher than WHO standard, while the average $\mathrm{Hg}$ in sediments was 160 times higher than PEL and ERM values and 560 times higher than TEL and ERL standards. The higher $\mathrm{Hg}$ in water and sediments in the surrounding areas of the wetlands is related to the existence of agricultural lands and use of fertilizers and pesticides by local farmers.

In order to identify and interpret the source of heavy metals more accurately, principal component analysis and correlation analysis were used. Pearson correlation demonstrated that $\mathrm{Co}, \mathrm{Cu}, \mathrm{As}$, and $\mathrm{Pb}$ in water samples and $\mathrm{Co}, \mathrm{Cr}, \mathrm{Cu}, \mathrm{As}$, and $\mathrm{Pb}$ in sediment samples had positive correlations. The PCA results for water samples showed that metals are located in three clusters; there are Co, As, and Cu in PC1 which are affected by municipal wastewater, $\mathrm{Pb}$ and $\mathrm{Hg}$ are in $\mathrm{PC} 2$ and their main source is probably agriculture activities and transportation. The PC3, which contains only $\mathrm{Cr}$, can be attributed to natural and geogenic sources. In sediment, metals in PC2 ( $\mathrm{Cu}$ and As) are probably affected by human activities, especially municipal wastewater, while the origin of metals in $\mathrm{PC} 1(\mathrm{Cr}$, $\mathrm{Co}$ and $\mathrm{Pb})$ can be both human due to agricultural and transportation activities (for $\mathrm{Pb}$ and $\mathrm{Co}$ ) and natural (for $\mathrm{Cr}$ ). Pearson correlation of $\mathrm{Cr}$ with $\mathrm{Co}$ and $\mathrm{Pb}$ as well as $\mathrm{As}$ and $\mathrm{Cu}$ in sediment and the high correlation of $\mathrm{Cu}$ with $\mathrm{Co}$ and $\mathrm{As}$ in water samples were consistent with PCA results for sediment and water, indicating the common sources of each heavy metal group.

The distribution of the heavy metal concentration in liver, muscle, and skin in $\mathrm{C}$. carpio was $\mathrm{Cu}>\mathrm{Pb}>\mathrm{Hg}>$ $\mathrm{Cr}>\mathrm{As}>\mathrm{Co}, \mathrm{Pb}>\mathrm{Cu}>\mathrm{Hg}>\mathrm{Cr}>\mathrm{As}>\mathrm{Co}$ and $\mathrm{Cu}>\mathrm{Pb}>\mathrm{Hg}>\mathrm{As}>\mathrm{Cr}>\mathrm{Co}$, whereas in L. auratus $\mathrm{Cu}>\mathrm{Pb}>\mathrm{As}>$ $\mathrm{Hg}>\mathrm{Cr}>\mathrm{Co}, \mathrm{Cu}>\mathrm{Pb}>\mathrm{As}>\mathrm{Hg}>\mathrm{Cr}>\mathrm{Co}$ and $\mathrm{Pb}>\mathrm{Cu}>\mathrm{As}>\mathrm{Cr}>\mathrm{Hg}>\mathrm{Co}$ respectively. The level of heavy metals accumulation was approximately similar among the studied species; $\mathrm{Cu}$ and $\mathrm{Pb}$ had the highest concentration, and Co had the lowest concentration in both fish species in liver, muscle, and skin tissues. Liver was the tissue which accumulated these elements more in $C$. carpio and $L$. auratus except for As and $\mathrm{Cr}$ in $C$. carpio,f furthermore, metals in $L$. auratus liver was more than $C$. carpio liver except for $\mathrm{Hg}$. $\mathrm{Cr}$, $\mathrm{Hg}$, and $\mathrm{Pb}$ were accumulated in $C$. carpio muscle more than $L$. auratus muscle, while $\mathrm{Co}, \mathrm{Cu}$, and $\mathrm{As}$ were mostly accumulated in $L$. Auratus muscle. Besides, metals were accumulated in $C$. carpio skin more than L. auratus skin except for $\mathrm{Pb}$. In general, the concentration of heavy metals in muscle was lower compared to liver;; fish muscles are the main edible parts. But muscles are not the tissue in which heavy metals are accumulated. A significant difference was recognized among the liver, muscle, and skin of the fish (C. carpio and $L$. auratus) in view of the bioaccumulation of the selected heavy metals. The results of ANOVA test in $C$. carpio species showed that there was a considerable difference between the amount of $\mathrm{Cr}$ and $\mathrm{As}$ in liver and skin tissues. In addition, a notable difference was observed between liver and muscle in relation to Co and As. In the case of $L$. auratus species, significant difference was clear between liver and skin for $\mathrm{Co}, \mathrm{Cu}, \mathrm{As}$, and $\mathrm{Hg}$ metals; furthermore, liver and skin had remarkable differences in terms of $\mathrm{Co}, \mathrm{Cu}$, and As metals. Mean values of $\mathrm{Pb}, \mathrm{Hg}$, As, and $\mathrm{Cu}$ were above the recommended limits of $\mathrm{FAO} / \mathrm{WHO} / \mathrm{EU}$ in the muscle tissue of $C$. carpio and $L$. auratus. As a result, since these fish are consumed by individuals, people should be cautious about the intake.

THQ, EDI, and CR provided by US Environmental Protection Agency were used to calculate and estimate the risk of exposure to heavy metals as a result of consuming two species of fish. The results of the 
indicators showed that EDI and THQ values propose no risk to human in regard with the consumption of the two fish species, but consumption of $C$. carpio has a higher risk than $L$. auratus. However, CR values for As and $\mathrm{Cr}$ were greater than $10^{-4}$, representing that the cancer risk posed by these metals exposure should not be ignored.

Blood, fingernail, toenail and hair samples were taken from Turkmen pregnant women for biological monitoring. considering the mean heavy metal contents in different organs, higher $\mathrm{Cr}, \mathrm{Co}, \mathrm{Cu}, \mathrm{As}, \mathrm{and} \mathrm{Hg}$ contents were found at fingernail, and the highest $\mathrm{Pb}$ content was observed at toenail, while the lowest concentration of heavy metals was observed in blood. Cu had the highest concentration among the studied elements in blood, fingernail, toenail, and hair; whereas the concentration of Co was observed to be lower in all organs. The mean concentration of blood heavy metals level was lower in non-fisherman family than in fisherman family except for $\mathrm{Cr}$, So the average concentration of lead in the fisherman family was significantly higher than non-fisherman families. The average blood metals concentration increased slightly with age, but the effect of age was only notable for cobalt metal. All blood samples had higher concentration than the standard value for Hg set by USEPA and WHO. People who had their teeth filled had lower mean metal concentration; therefore, dental amalgam did not display an association with heavy metal accumulation in blood. Place of residence, fishermen families, dental amalgam, and age had no significant effect on the concentration of heavy metals in hair. In addition, no specific trend was observed regarding metals changes in relation to the mentioned factors. what's more, the concentration of As and $\mathrm{Hg}$ in hair samples in the fishermen families was higher than the non-fishermen families. Heavy metals concentration in water, sediment, and two fish species proved that the amount of Hg was higher than the specified standards, especially for sediment which was much higher than the permissible standards. It can be said that $\mathrm{Hg}$ accumulation in water and sediment has led to an increase concentration in fish species and consequently in pregnant women's hair in the region. In our study, 75\% of the recorded hair samples were higher than Hg references suggested by USEPA and WHO. In addition, people with filled teeth showed higher levels of $\mathrm{Hg}$ and $\mathrm{Pb}$ in the first age group; the average concentration of $\mathrm{Pb}$ and $\mathrm{Hg}$ was higher. It can be concluded that the increase of age had no influence on metals levels of hair. The mean concentration of all metals in fingernail was higher than toenail except for $\mathrm{Pb}$; ; also, a significant difference was observed between the concentration of $\mathrm{Cr}, \mathrm{Co}, \mathrm{Hg}$ and $\mathrm{Pb}$ metals in toenail and fingernail.

ANOVA was conducted to compare human organs;; the result indicated that there was no significant difference in relation to heavy metals in blood and hair, while there was a statistically huge difference between the heavy metals $\mathrm{Cr}, \mathrm{Co}, \mathrm{Cu}, \mathrm{As}$, and $\mathrm{Hg}$ in hair and toenail and between the heavy metals $\mathrm{Cr}$, $\mathrm{Cu}$, $\mathrm{As}, \mathrm{Hg}$, and $\mathrm{Pb}$ in hair and fingernail. In addition, $\mathrm{Cr}, \mathrm{Co}, \mathrm{Hg}$, and $\mathrm{Pb}$ metals in toenail and fingernail and $\mathrm{Cr}$, $\mathrm{Co}, \mathrm{As}$, and $\mathrm{Pb}$ metals in toenail and hair had notable differences.

The study showed that the level of heavy metals in water and sediment, especially $\mathrm{Hg}$, are threatening the various fish species which are principle and preferable praise for various migratory shorebirds as well as residents. Therefore, the assessment of wetland habitats, especially Ramsar sites, should be done to understand the current status of heavy metals in major species, including migratory, resident migratory 
and resident shorebirds. Also, relevant organizations must control sensitive habitats to mitigate further environmental heavy metal pollution.

US Food and Drug Administration (USFDA 2004) and Environmental Protection Agency (USEPA 2005) recommends pregnant women, women of childbearing age, nursing mothers, and young children, to avoid seafood with high levels of $\mathrm{Hg}$. In this regard, the necessary information should be provided in this area. It is suggested that biological monitoring be performed for different groups, especially young children.

Due to our small sample size, the results may not be valid for all pregnant women; therefore, it is necessary to use more samples to confirm the results and the relationship between the various studied factors and the level of metals in different organs. In general, due to the limitations of this study, however, the results of this study can be used to be compared with other studies.

Although there is no specific organization for pregnant women's biological monitoring in Iran, these results may draw the attention of environmental and health authorities to a national biological monitoring program, especially among vulnerable groups (children and women of childbearing age).

\section{Declarations}

\section{Ethical Approval}

Human bio monitoring was performed based on the protocol specified by the Medical Ethical Committee of Iran in collaboration with the staff of the health center (Ethical Committee of Golestan University of Medical Sciences.(IR.GOUMS.REC.2019.126). Ethical principles and privacy were fully observed.

\section{Consent to Participate}

A written consent was received from the participants while completing the questionnaire.

Turkmen pregnant women from two villages, Qharesou and Chpaqli, living in the northern part of Miankale wetland participate in this study.

\section{Consent to Publish}

The authors declare that this paper could be published in your journal, ESPR, after receiving acceptance.

\section{Authors Contributions}

All authors contributed in whole writing process are:

Abbas Esmaili-sari as corresponding author, Zahra Shaabani as principle author, Ali MashinchianMoradi, Lobat Taghavi and Forough Farsad as co-authors.

\section{Funding}


Not Applicable

\section{Competing Interest}

The authors declare that they have no competing interest.

\section{Availability of Data and Materials}

All data and materials used in the paper are available in reference link or Doi of used papers.

\section{References}

1. Abadi M, Zamani A, Parizanganeh A, Khosravi Y, Badiee H (2018) "Heavy metals and arsenic content in water along the southern Caspian. coasts in Iran" Environmental Science Pollution Research 25(24):23725-23735. https://doi.org/10.1007/s11356-018-2455-7

2. Abd-Elghany SM, Zaher HA, Elgazzar MM, Sallam KI (2020) Effect of boiling and grilling on some heavy metal residues in crabs and shrimps from the Mediterranean Coast at Damietta region with their probabilistic health risk assessment. J Food Compos Anal 93:103606. https://doi.org/10.1016/j.jfca.2020.103606

3. Abdulrahman F, Akan J, Chellube Z, Waziri M (2012) "Levels of heavy metals in human hair and nail samples from Maiduguri Metropolis, Borno State. Nigeria" World Environ 2(4):81-89. doi 10.5923/j.env.20120204.05

4. Adel M, Dadar M, Fakhri Y, Oliveri Conti G, Ferrante M (2016) Heavy metal concentration in muscle of pike (Esox lucius Linnaeus, 1758) from Anzali international wetland, southwest of the Caspian Sea and their consumption risk assessment. Toxin reviews 35(3-4):217-223. https://doi.org/10.1080/15569543.2016.1223694

5. Agah H, Hashtroodi M, Baeyens W (2011) Trace metals analysis in the sediments of the Southern Caspian Sea. Journal of the Persian Gulf 2(6):1-12. http://jpg.inio.ac.ir

6. Ahmed MK, Baki MA, Kundu GK, Islam MS, Islam MM, Hossain MM (2016) "Human health risks from heavy metals in fish of Buriganga river. Bangladesh" SpringerPlus 5(1):1-12. https://doi.org/10.1186/s40064-016-3357-0

7. Akindele EO, Omisakin OD, Oni OA, Aliu OO, Omoniyi GE, Akinpelu OT (2020) Heavy metal toxicity in the water column and benthic sediments of a degraded tropical stream. Ecotoxicol Environ Saf 190:110153. https://doi.org/10.1016/j.ecoenv.2019.110153

8. Al-Saleh I (2020) Reference values for heavy metals in the urine and blood of Saudi women derived from two human biomonitoring studies. Int J Hyg Environ Health 225:113473. doi:10.1016/j.ijheh.2020.113473

9. Alipour H, Banagar GR (2018) "Health risk assessment of selected heavy metals in some edible fishes from Gorgan Bay. Iran" Iranian Journal of Fisheries Sciences 17(1):21-34.

DOI:10.22092/IJFS.2018.115582 
10. Lahijani AK, Naderi Beni HA, Tavakoli V (2018) "Heavy metals in coastal sediments of South Caspian Sea: natural or anthropogenic source?". Caspian Journal of Environmental Sciences 16(1):45-61. http://hdl.handle.net/1834/13516

11. Alrobaian M, Arida H (2019) "Assessment of heavy and toxic metals in the blood and hair of Saudi Arabia smokers using modern analytical techniques." International journal of analytical chemistry 2019. https://doi.org/10.1155/2019/7125210

12. Angerer J, Aylward LL, Hays SM, Heinzow B, Wilhelm M (2011) Human biomonitoring assessment values: approaches and data requirements. Int J Hyg Environ Health 214(5):348-360.

DOI:10.1016/j.jheh.2011.06.002

13. Angerer J, Ewers U, Wilhelm M (2007) Human biomonitoring: state of the art. Int J Hyg Environ Health 210(3-4):201-228. DOI:10.1016/j.ijheh.2007.01.024

14. Asante K (2015) Assessment of heavy metal contamination in water, sediment and fish from the Jimi Reservoir, Obuasi. http://ir.knust.edu.gh/

15. Ashayeri NY, Keshavarzi B (2019) "Geochemical characteristics, partitioning, quantitative source apportionment, and ecological and health risk of heavy metals in sediments and water: A case study in Shadegan Wetland. Iran" Marine pollution bulletin 149:110495.

https://doi.org/10.1016/j.marpolbul.2019.110495

16. Ashrap P, Watkins DJ, Mukherjee B, Boss J, Richards MJ, Rosario Z, Vélez-Vega CM, Alshawabkeh A, Cordero JF, Meeker JD (2020) "Predictors of urinary and blood metal (loid) concentrations among pregnant women in northern Puerto Rico. " Environmental research 183:109178.

DOI:10.1016/j.envres.2020.109178

17. Atique Ullah AKM, Akter M, Musarrat M, Quraishi SB (2019) Evaluation of Possible Human Health Risk of Heavy Metals from the Consumption of Two Marine Fish Species Tenualosa ilisha and Dorosoma cepedianum. Biol Trace Elem Res 191(2):485-494. doi:10.1007/s12011-018-1616-3

18. ATSDR (2010) (Agency for toxic substance and disease registry) Public health assessment and health consultation. Washington:, CENEX supply and marketing, Incorporated, Quicy, County G, https://www.atsdr.cdc.gov

19. Aytekin T, Kargın D, Çoğun HY, Temiz Ö, Varkal HS, Kargın F (2019) "Accumulation and health risk assessment of heavy metals in tissues of the shrimp and fish species from the Yumurtalik coast of Iskenderun Gulf. Turkey" Heliyon 5(8):e02131. https://doi.org/10.1016/j.ecoenv.2018.04.035

20. Baki MA, Hossain MM, Akter J, Quraishi SB, Shojib MFH, Ullah AA, Khan MF (2018) "Concentration of heavy metals in seafood (fishes, shrimp, lobster and crabs) and human health assessment in Saint Martin Island. Bangladesh" Ecotoxicology environmental safety 159:153-163. https://doi.org/10.1016/j.ecoenv.2018.04.035

21. Basim Y, Khoshnood Z (2016) "Target hazard quotient evaluation of cadmium and lead in fish from Caspian. Sea" Toxicology industrial health 32(2):215-220. https://doi.org/10.1177/0748233713498451 
22. Bianchi M, Chopin F, Farmer T, Franz N, Fuentevilla C, Garibaldi L, Grainger N, Jara F, Karunasagar I, Laurenti A (2014) "FAO: The State of World Fisheries and Aquaculture". Food and Agriculture Organization of the United Nations, Rome. https://scholar.google.com/

23. Canada H (2010) "Report on Human Biomonitoring of Environmental Chemicals in Canada-Results of the Canadian Health. Measures Survey Cycle 1:2007-2009. https://scholar.google.com/

24. Canada H (2013) Second report on human biomonitoring of environmental chemicals in Canada, Health Canada Ottawa, Ontario, Canada. https://scholar.google.com

25. Canada H (2017) "Fourth Report on Human Biomonitoring of Environmental Chemicals in Canada." https://scholar.google.com

26. CCME (1999) "Canadian sediment quality guidelines for the protection of aquatic life:mercury, zinc, lead, copper, chrome and cadmium. In: Canadian Environmental Quality Guidelines". Canadian Council of Ministers of the Environment, Winnipeg. https://scholar.google.com

27. Chaturvedi A, Bhattacharjee S, Singh AK, Kumar V (2018) A new approach for indexing groundwater heavy metal pollution. Ecol Ind 87:323-331. https://doi.org/10.1016/j.ecolind.2017.12.052

28. Chen L, Liang S, Liu M, Yi Y, Mi Z, Zhang Y, Li Y, Qi J, Meng J, Tang X (2019) Trans-provincial health impacts of atmospheric mercury emissions in China. Nature communications 10(1):1-12. https://doi.org/10.1038/s41467-019-09080-6

29. Cherrie JW, Semple S, Christopher Y, Saleem A, Hughson GW, Philips A (2006) "How important is inadvertent ingestion of hazardous substances at work?". The Annals of Occupational Hygiene 50(7):693-704. https:// doi.org/10.1093/annhyg/mel035

30. Chien L-C, Hung T-C, Choang K-Y, Yeh C-Y, Meng P-J, Shieh M-J, Han B-C (2002) Daily intake of TBT, $\mathrm{Cu}, \mathrm{Zn}, \mathrm{Cd}$ and As for fishermen in Taiwan. Science of the total environment 285(1-3):177-185. https://doi.org/10.1016/S0048-9697(01)00916-0

31. Christensen JM (1995) Human exposure to toxic metals: factors influencing interpretation of biomonitoring results. Science of the total environment 166(1-3):89-135. https://doi.org/10.1016/0048-9697(95)04478-J

32. Christophoridis C, Kosma A, Evgenakis E, Bourliva A, Fytianos K (2019) "Determination of heavy metals and health risk assessment of cheese products consumed in Greece." Journal of Food Composition and Analysis 82: 103238. Determination of heavy metals and health risk assessment of cheese products consumed in Greece https://doi.org/10.1016/j.jfca.2019.103238

33. Clewell HJ, Tan YM, Campbell JL, Andersen ME (2008) "Quantitative interpretation of human biomonitoring data." Toxicol Appl Pharmacol 231(1): 122-133.

https://doi.org/10.1016/j.taap.2008.04.021

34. Coffie J (2015) Assessment of physicochemical properties and heavy metals in water, sediment and fish (oreochromis niloticus) from the Upper Volta basin (stratum vii), Ghana. http://hdl.handle.net/123456789/7167

35. Çoğun H, Yüzereroğlu T, Kargin F, Firat Ö (2005) "Seasonal variation and tissue distribution of heavy metals in shrimp and fish species from the yumurtalik coast of iskenderun gulf, mediterranean." 
Bulletin of Environmental Contamination \& Toxicology 75(4). https://web.b.ebscohost.com/

36. Cooper CB, Doyle ME, Kipp K (1991) "Risks of consumption of contaminated seafood: the Quincy Bay case study". Environ Health Perspect 90:133-140. https://doi.org/10.1289/ehp.90-1519503

37. Council NR (2000) Toxicological effects of methylmercury. National Academy Press, Washington, DC

38. Dadar M, Adel M, Ferrante M, Nasrollahzadeh Saravi H, Copat C, Oliveri Conti G (2016) "Potential risk assessment of trace metals accumulation in food, water and edible tissue of rainbow trout (Oncorhynchus mykiss) farmed in Haraz River, northern Iran. " Toxin Reviews 35(3-4):141-146. https://doi.org/10.1080/15569543.2016.1217023

39. Davidson PW, Myers GJ, Weiss B (2004) "Mercury exposure and child development outcomes." Pediatrics 113(Supplement 3): 1023-1029. DOI:10.1542/peds.113.4.S1.1023

40. Demirezen D, Aksoy A (2006) Heavy metal levels in vegetables in Turkey are within safe limits for $\mathrm{Cu}$, Zn, Ni and exceeded for Cd and Pb. J Food Qual 29(3):252-265. doi/epdf/10.1111/j.17454557.2006.00072

41. Deng M, Yang X, Dai X, Zhang Q, Malik A, Sadeghpour A (2020) Heavy metal pollution risk assessments and their transportation in sediment and overlay water for the typical Chinese reservoirs. Ecol Ind 112:106166. https://doi.org/10.1016/j.ecolind.2020.106166

42. Dessie BK, Melaku S, Robele Gari S, Ayele BT, Desta AF, Mihret A (2020) "Evaluation of toxic elements in nails of tannery workers in Addis Ababa. Ethiopia" Microchemical Journal 159:105589. https://doi.org/10.1016/j.microc.2020.105589

43. Dhanakumar S, Solaraj G, Mohanraj R (2015) "Heavy metal partitioning in sediments and bioaccumulation in commercial fish species of three major reservoirs of river Cauvery delta region. India" Ecotoxicology environmental safety 113:145-151.

https://doi.org/10.1016/j.ecoenv.2014.11.032

44. Elkady AA, Sweet ST, Wade TL, Klein AG (2015) "Distribution and assessment of heavy metals in the aquatic environment of Lake Manzala. Egypt" Ecological Indicators 58:445-457.

https://doi.org/10.1016/j.ecolind.2015.05.029

45. EPA (2004) Risk assessment guidance for superfund, Human Health Evaluation Manual (Part a). vol. I. https://www.epa.gov/risk/risk-assessment-guidance

46. Esilaba F, Moturi WN, Mokua M, Mwanyika T (2020) "Human Health Risk Assessment of Trace Metals in the Commonly Consumed Fish Species in Nakuru Town. Kenya" Environmental Health Insights 14:1178630220917128. doi:10.1177/1178630220917128

47. Eykelbosh A, Werry K, Kosatsky T (2018) "Leveraging the Canadian Health Measures Survey for environmental health research. " Environment International 119:536-543. doi:10.1016/j.envint.2018.07.011

48. Ezemonye LI, Adebayo PO, Enuneku AA, Tongo I, Ogbomida E (2019) "Potential health risk consequences of heavy metal concentrations in surface water, shrimp (Macrobrachium macrobrachion) and fish (Brycinus longipinnis) from Benin River. Nigeria" Toxicology Reports 6:1-9. https://doi.org/10.1016/j.toxrep.2018.11.010 
49. Fallah AA, Saei-Dehkordi SS, Nematollahi A, Jafari T (2011) Comparative study of heavy metal and trace element accumulation in edible tissues of farmed and wild rainbow trout (Oncorhynchus mykiss) using ICP-OES technique. Microchem J 98(2):275-279.

https://doi.org/10.1016/j.microc.2011.02.007

50. Fan H, Chen S, Li Z, Liu P, Xu C, Yang X (2020) "Assessment of heavy metals in water, sediment and shellfish organisms in typical areas of the Yangtze River Estuary. China" Marine pollution bulletin 151:110864. https://doi.org/10.1016/j.marpolbul.2019.110864

51. FAO (1983) FAO (1983) Compilation of legal limits for hazardous substances in fish and fishery products. FAO Fisheries Circular. 764. FAO, Rome, 102p. Available from:

http://www.fao.org/fi/oldsite/eims_search/1_dett.asp,calling = simple_s_result\&lang = fr\&pub_id = 65155

52. Faure S, Noisel N, Werry K, Karthikeyan S, Aylward LL, St-Amand A (2020) "Evaluation of human biomonitoring data in a health risk based context: An updated analysis of population level data from the Canadian Health Measures Survey" International Journal of Hygiene Environmental Health 223(1): 267-280. https://doi.org/10.1016/j.ijheh.2019.07.009

53. Feed Fa (2013) Maximum limit of heavy metals. Iranian National Standard, Institute of Standard and Industrial Research of Iran

54. Fierens S, Rebolledo J, Versporten A, Brits E, Haufroid V, De Plaen P, Van Nieuwenhuyse A (2016) "Human biomonitoring of heavy metals in the vicinity of non-ferrous metal plants in Ath. Belgium" Archives of Public Health 74(1):1-11. https://doi.org/10.1186/s13690-016-0154-8

55. Finley BL, Monnot AD, Paustenbach DJ, Gaffney SH (2012) Derivation of a chronic oral reference dose for cobalt. Regul Toxicol Pharmacol 64(3):491-503.

https://doi.org/10.1016/j.yrtph.2012.08.022

56. Food F (2018) "agriculture organization of the United Nations. 2012." Producción. Ganadería. Online http://faostat. fao. org/site/573/default. aspx\# ancor

57. Fuentes-Gandara F, Herrera-Herrera C, Pinedo-Hernández J, Marrugo-Negrete J, Díez S (2018) "Assessment of human health risk associated with methylmercury in the imported fish marketed. in the Caribbean" Environmental research 165:324-329. https://doi.org/10.1016/j.envres.2018.05.001

58. Ganzleben C, Antignac J-P, Barouki R, Castaño A, Fiddicke U, Klánová J, Lebret E, Olea N, Sarigiannis D, Schoeters GR (2017) Human biomonitoring as a tool to support chemicals regulation in the European Union. Int J Hyg Environ Health 220(2 Pt A):94-97. doi:10.1016/j.ijheh.2017.01.007

59. Garnero PL, de los Angeles Bistoni M, Monferran M (2020) "Trace element concentrations in six fish species from freshwater lentic environments and evaluation of possible health risks according to international standards of consumption." Environmental science and pollution research international. Vol. 27 Issue 22, p27598-27608. 11p

60. GB2762 (2017) National Food Safety Standards, 2017. http://down.foodmate.net/ standard/sort/3/50748.html 
61. Ghorbanzadeh Zaferani SG, Machinchian Moradi A, Mousavi Nadushan R, Sari A, Fatemi S (2016) Distribution pattern of heavy metals in the surficial sediment of Gorgan Bay (South Caspian Sea, Iran). Iranian Journal of Fisheries Sciences 15(3):1144-1166.

http://aquaticcommons.org/id/eprint/22939

62. Gimeno-García E, Andreu V, Boluda R (1996) Heavy metals incidence in the application of inorganic fertilizers and pesticides to rice farming soils. Environmental pollution 92(1):19-25. https://doi.org/10.1016/0269-7491(95)00090-9

63. Gracia L, Marrugo JL, Alvis EM (2010) "Contaminación por mercurio en humanos y peces en el municipio de Ayapel, Córdoba, Colombia, 2009". Revista Facultad Nacional de Salud Pública 28(2):118-124

64. Griboff J, Wunderlin DA, Monferran MV (2017) "Metals, As and Se determination by inductively coupled plasma-mass spectrometry (ICP-MS) in edible fish collected from three eutrophic reservoirs. Their consumption represents a risk for human health? " Microchemical Journal 130:236-244. https://doi.org/10.1016/j.microc.2016.09.013

65. Haines DA, Saravanabhavan G, Werry K, Khoury C (2017) "An overview of human biomonitoring of environmental chemicals in the Canadian Health Measures Survey: 2007-2019". Int J Hyg Environ Health 220(2):13-28. https://doi.org/10.1016/j.ijheh.2016.08.002

66. Hashmi MZ, Malik RN, Shahbaz M (2013) "Heavy metals in eggshells of cattle egret (Bubulcus ibis) and little egret (Egretta garzetta) from the Punjab province. Pakistan" Ecotoxicology Environmental safety 89:158-165. https://doi.org/10.1016/j.ecoenv.2012.11.029

67. Hays SM, Aylward LL (2009) Using biomonitoring equivalents to interpret human biomonitoring data in a public health risk context. J Appl Toxicol 29(4):275-288. https://doi.org/10.1002/jat.1410

68. Hrubá F, Strömberg U, Černá M, Chen C, Harari F, Harari R, Horvat M, Koppová K, Kos A, Krsková A (2012) "Blood cadmium, mercury, and lead in children: an international comparison of cities in six European countries, and China, Ecuador, and Morocco. " Environment international 41:29-34. https://doi.org/10.1016/j.envint.2011.12.001

69. Humbatov FY, Ahmadov MM, Balayev VS, Suleymanov BA (2015) "Trace metals in water samples taken from Azerbaijan sector of Caspian Sea. " J Chem 9:288-295. doi:10.17265/19347375/2015.04.007

70. Ikem A, Egiebor NO (2005) "Assessment of trace elements in canned fishes (mackerel, tuna, salmon, sardines and herrings) marketed in Georgia and Alabama (United States of America)". Journal of food composition analysis 18(8):771-787. https://doi.org/10.1016/j.jfca.2004.11.002

71. Iran Fisheries Organization (1398) Statistical Yearbook of Iran Fisheries Organization. Deputy of Planning and Resource Management. Planning and Budget Office, Planning and Statistics Department

72. IRIS (2010) "Agency Uep (Ed.), Integrated Risk Information System." Cincinnati, OH: 4-9

73. Islam MA, Das B, Quraishi SB, Khan R, Naher K, Hossain SM, Karmaker S, Latif SA, Hossen MB (2020) "Heavy metal contamination and ecological risk assessment in water and sediments of the Halda 
river, Bangladesh: A natural fish breeding ground". Mar Pollut Bull 160:111649. https://doi.org/10.1016/j.marpolbul.2020.111649

74. Javed M, Usmani N (2016) "Accumulation of heavy metals and human health risk assessment via the consumption of freshwater fish Mastacembelus armatus inhabiting, thermal power plant effluent loaded canal." SpringerPlus 5(1): 776. https://doi.org/10.1186/s40064-016-2471-3

75. Jedrychowski W, Jankowski J, Flak E, Skarupa A, Mroz E, Sochacka-Tatara E, Lisowska-Miszczyk I, Szpanowska-Wohn A, Rauh V, Skolicki Z (2006) Effects of prenatal exposure to mercury on cognitive and psychomotor function in one-year-old infants: epidemiologic cohort study in Poland. Ann Epidemiol 16(6):439-447. https://doi.org/10.1016/j.annepidem.2005.06.059

76. Jeong KS, Ha E, Shin JY, Park H, Hong Y-C, Ha M, Kim S, Lee S-J, Lee KY, Kim JH (2017) Blood heavy metal concentrations in pregnant Korean women and their children up to age 5 years: Mothers' and Children's Environmental Health (MOCEH) birth cohort study. Sci Total Environ 605:784-791. https://doi.org/10.1016/j.scitotenv.2017.06.007

77. Jeszka-Skowron M, Zgoła-Grześkowiak A, Stanisz E, Waśkiewicz A (2017) Potential health benefits and quality of dried fruits: Goji fruits, cranberries and raisins. Food Chem 221:228-236. https://doi.org/10.1016/j.foodchem.2016.10.049

78. Jezierska B, Witeska M (2006) "The metal uptake and accumulation in fish living in polluted waters". In: Soil and water pollution monitoring, protection and remediation. Springer, pp 107-114. DOlhttps://doi.org/10.1007/978-1-4020-4728-2_6

79. Kargın F, Çoğun H (1999) Metal interactions during accumulation and elimination of zinc and cadmium in tissues of the freshwater fish Tilapia nilotica. Bull Environ Contam Toxicol 63(4):511519

80. Keshavarzi B, Hassanaghaei M, Moore F, Mehr MR, Soltanian S, Lahijanzadeh AR, Sorooshian A (2018) "Heavy metal contamination and health risk assessment in three commercial fish species. in the Persian Gulf" Marine pollution bulletin 129(1):245-252.

https://doi.org/10.1016/j.marpolbul.2018.02.032

81. Kortei NK, Heymann ME, Essuman EK, Kpodo FM, Akonor PT, Lokpo SY, Boadi NO, Ayim-Akonor M, Tettey C (2020) Health risk assessment and levels of toxic metals in fishes (Oreochromis noliticus and Clarias anguillaris) from Ankobrah and Pra basins: Impact of illegal mining activities on food safety. Toxicology Reports 7:360-369. https://doi.org/10.1016/j.toxrep.2020.02.011

82. Koseoglu E, Koseoglu R, Kendirci M, Saraymen R, Saraymen B (2017) Trace metal concentrations in hair and nails from Alzheimer's disease patients: Relations with clinical severity. J Trace Elem Med Biol 39:124-128. https://doi.org/10.1016/j.jtemb.2016.09.002

83. Kris-Etherton PM, Harris WS, Appel LJ (2002) Fish consumption, fish oil, omega-3 fatty acids, and cardiovascular disease. Circulation 106(21):2747-2757.

https://doi.org/10.1161/01.CIR.0000038493.65177.94

84. LaKind JS, Aylward LL, Brunk C, DiZio S, Dourson M, Goldstein DA, Kilpatrick ME, Krewski D, Bartels MJ, Barton HA (2008) "Guidelines for the communication of Biomonitoring Equivalents: report from 
the Biomonitoring Equivalents Expert Workshop". Regul Toxicol Pharmacol 51(3):S16-S26. https://doi.org/10.1016/j.yrtph.2008.05.007

85. Lee JW, Lee CK, Moon CS, Choi IJ, Lee KJ, Yi S-M, Jang B-K, jun Yoon B, Kim DS, Peak D (2012) Korea National Survey for Environmental Pollutants in the Human Body 2008: heavy metals in the blood or urine of the Korean population. Int J Hyg Environ Health 215(4):449-457. https://doi.org/10.1016/j.ijheh.2012.01.002

86. Lemos VA, Novaes GdS, de Carvalho AL, Gama EM, Santos AG (2009) Determination of copper in biological samples by flame atomic absorption spectrometry after precipitation with Me-BTAP. Environ Monit Assess 148(1-4):245-253. https://doi.org/10.1007/s10661-008-0155-3

87. Lin L, Li C, Yang W, Zhao L, Liu M, Li Q, Crittenden JC (2020) "Spatial variations and periodic changes in heavy metals in surface water and sediments of the Three Gorges Reservoir. China" Chemosphere 240:124837. https://doi.org/10.1016/j.chemosphere.2019.124837

88. Liu C-W, Liang C-P, Huang FM, Hsueh Y-M (2006) Assessing the human health risks from exposure of inorganic arsenic through oyster (Crassostrea gigas) consumption in Taiwan. Sci Total Environ 361(1-3):57-66. https://doi.org/10.1016/j.scitotenv.2005.06.005

89. Loaiza I, De Troch M, De Boeck G (2018) "Potential health risks via consumption of six edible shellfish species collected from Piura-Peru" Ecotoxicology environmental safety 159: 249-260. https://doi.org/10.1016/j.ecoenv.2018.05.005

90. Louro H, Heinälä M, Bessems J, Buekers J, Vermeire T, Woutersen M, van Engelen J, Borges T, Rousselle C, Ougier E, Alvito P, Martins C, Assunção R, Silva MJ, Pronk A, Schaddelee-Scholten B, Del Carmen M, Gonzalez M, de Alba A, Castaño S, Viegas T, Humar-Juric L, Kononenko A, Lampen AM, Vinggaard G, Schoeters M, Kolossa-Gehring, Santonen T (2019) Human biomonitoring in health risk assessment in Europe: Current practices and recommendations for the future. Int $\mathrm{J}$ Hyg Environ Health 222(5):727-737. https://doi.org/10.1016/j.ijheh.2019.05.009

91. Marrugo-Negrete JL, Ruiz-Guzmán JA, Díez S (2013) Relationship Between Mercury Levels in Hair and Fish Consumption in a Population Living Near a Hydroelectric Tropical Dam. Biol Trace Elem Res 151(2):187-194. https://doi.org/10.1007/s12011-012-9561-z

92. Maurya PK, Malik D, Yadav KK, Kumar A, Kumar S, Kamyab H (2019) Bioaccumulation and potential sources of heavy metal contamination in fish species in River Ganga basin: Possible human health risks evaluation. Toxicology reports 6:472-481. https://doi.org/10.1016/j.toxrep.2019.05.012

93. McDowell MA, Dillon CF, Osterloh J, Bolger PM, Pellizzari E, Fernando R, de Oca RM, Schober SE, Sinks T, Jones RL (2004) "Hair mercury levels in US children and women of childbearing age: reference range data from NHANES 1999-2000." Environmental health perspectives 112(11): 11651171. https://doi.org/10.1289/ehp.7046

94. Miao X, Hao Y, Liu H, Xie Z, Miao D, He X (2021) Effects of heavy metals speciations in sediments on their bioaccumulation in wild fish in rivers in Liuzhou-A typical karst catchment in southwest China. Ecotoxicol Environ Saf 214:112099. https://doi.org/10.1016/j.ecoenv.2021.112099 
95. Micó C, Recatalá L, Peris M, Sánchez J (2006) Assessing heavy metal sources in agricultural soils of an European Mediterranean area by multivariate analysis. Chemosphere 65(5):863-872. https://doi.org/10.1016/j.chemosphere.2006.03.016

96. Mortada WI, Sobh MA, El-Defrawy MM, Farahat SE (2002) "Reference intervals of cadmium, lead, and mercury in blood, urine, hair, and nails among residents in Mansoura city, Nile delta. Egypt" Environmental research 90(2):104-110. https://doi.org/10.1006/enrs.2002.4396

97. Muhammad S, Ahmad K (2020) Heavy metal contamination in water and fish of the Hunza River and its tributaries in Gilgit-Baltistan: evaluation of potential risks and provenance. Environmental Technology Innovation 20:101159. https://doi.org/10.1016/j.eti.2020.101159

98. Nabavi SF, Nabavi SM, Latifi AM, Eslami S, Ebrahimzadeh MA (2012) "Determination of trace elements level of pikeperch collected from the Caspian Sea" Bulletin of environmental contamination toxicology 88(3): 401-405. https:// doi.org/10.1007/s00128-011-0513-7

99. NOAA (2012) National Oceanic and Atmospheric Administration, USA. Chapter 173-204 WAC, 1991/95. WA Dept. of Ecology

100. Ogbomida ET, Nakayama SM, Bortey-Sam N, Oroszlany B, Tongo I, Enuneku AA, Ozekeke O, Ainerua MO, Fasipe IP, Ezemonye LI (2018) "Accumulation patterns and risk assessment of metals and metalloid in muscle and offal of free-range chickens, cattle and goat in Benin City. Nigeria" Ecotoxicology environmental safety 151:98-108. https://doi.org/10.1016/j.ecoenv.2017.12.069

101. Okati N, Esmaili-sari A (2018) "Determination of Mercury Daily Intake and Hair-to-Blood Mercury Concentration Ratio in People Resident of the Coast of the Persian Gulf. Iran" Archives of Environmental Contamination Toxicology 74(1):140-153. https://doi.org/10.1007/s00244-017-0456z

102. Özparlak H, Arslan G, Arslan E (2012) "Determination of some metal levels in muscle tissue of nine fish species from the Beyşehir Lake, Turkey" Turkish Journal of Fisheries Aquatic Sciences 12(4). DOI:10.4194/1303-2712-v12_4_04

103. Pandiyan J, Mahboob S, Govindarajan M, Al-Ghanim KA, Ahmed Z, Al-Mulhm N, Jagadheesan R, Krishnappa K (2021) An assessment of level of heavy metals pollution in the water, sediment and aquatic organisms: A perspective of tackling environmental threats for food security. Saudi Journal of Biological Sciences 28(2):1218-1225. https://doi.org/10.1016/j.sjbs.2020.11.072

104. Prokopowicz A, Pawlas N, Ochota P, Szuła M, Sobczak A, Pawlas K (2014) "Blood Levels of Lead, Cadmium, and Mercury in Healthy Women in their 50s in an Urban Area of Poland: A Pilot Study." Polish Journal of Environmental Studies 23(1)

105. Przybylowicz A, Chesy P, Herman M, Parczewski A, Walas S, Piekoszewski W (2012) "Examination of distribution of trace elements in hair, fingernails and toenails as alternative biological materials. Application of chemometric methods" Central European Journal of Chemistry 10(5):1590-1599. https://doi.org/10.2478/s11532-012-0089-z

106. Rajeshkumar S, Li X (2018) "Bioaccumulation of heavy metals in fish species from the Meiliang Bay, Taihu Lake. China" Toxicology Reports 5:288-295. https://doi.org/10.1016/j.toxrep.2018.01.007 
107. Ramsar (1975) from https://rsis.ramsar.org/ris/36

108. Sadeghi P, Loghmani M, Frokhzad S (2020) "Human health risk assessment of heavy metals via consumption of commercial marine fish (Thunnus albacares, Euthynnus affinis, and Katsuwonus pelamis) in Oman Sea". Environ Sci Pollut Res 27(13):14944-14952.

https://doi.org/10.1007/s11356-020-07907-0

109. Saha N, Mollah M, Alam M, Rahman MS (2016) Seasonal investigation of heavy metals in marine fishes captured from the Bay of Bengal and the implications for human health risk assessment. Food Control 70:110-118. http://dx.doi.org/10.1016/j.foodcont.2016.05.040

110. Saravi SS, Karami B, Karami S, Shokrzadeh M (2012) "Evaluation of metal pollution in fish and water collected from Gorgan coast of the Caspian Sea. Iran" Bulletin of environmental contamination toxicology 89(2):419-423. https://doi.org/10.1007/s00128-012-0670-3

111. Schertzinger G, Ruchter N, Sures B (2018) Metal accumulation in sediments and amphipods downstream of combined sewer overflows. Science of The Total Environment 616:1199-1207. https://doi.org/10.1016/j.scitotenv.2017.10.199

112. Sharafi K, Nodehi RN, Mahvi AH, Pirsaheb M, Nazmara S, Mahmoudi B, Yunesian M (2019) Bioaccessibility analysis of toxic metals in consumed rice through an in vitro human digestion model-Comparison of calculated human health risk from raw, cooked and digested rice. Food Chem 299:125126. https://doi.org/10.1016/j.foodchem.2019.125126

113. Solgi E, Alipour H, Majnooni F (2018) "Assessment of Heavy metal concentrations in the muscles of Common carp (Cyprinus carpio L., 178) from the southern coast of the Caspian Sea and potential risks to human health." Iranian Scientific Fisheries Journal,1(27): DOI:10.22.92/ISFJ.2018.116453

114. Tabari S, Saravi SSS, Bandany GA, Dehghan A, Shokrzadeh M (2010) "Heavy metals (Zn, Pb, Cd and $\mathrm{Cr}$ ) in fish, water and sediments sampled form Southern Caspian Sea, Iran" Toxicology industrial health 26(10): 649-656. https://doi.org/10.1177\%2F0748233710377777

115. Takagi Y, Matsuda S, Imai S, Ohmori Y, Masuda T, Vinson J, Mehra M, Puri B, Kaniewski A (1986) Trace elements in human hair: an international comparison. Bull Environ Contam Toxicol 36(1):793800. https://doi.org/10.1007/BF01623585

116. Tian K, Wu Q, Liu P, Hu W, Huang B, Shi B, Zhou Y, Kwon B-O, Choi K, Ryu J, Seong Khim J, Wang T (2020) "Ecological risk assessment of heavy metals in sediments and water from the coastal areas of the Bohai Sea and the Yellow Sea. " Environment International 136:105512. https://doi.org/10.1016/j.envint.2020.105512

117. Töre Y, Ustaoğlu F, Tepe Y, Kalipci E (2021) Levels of toxic metals in edible fish species of the Tigris River (Turkey); Threat to public health. Ecol Ind 123:107361.

https://doi.org/10.1016/j.ecolind.2021.107361

118. Ullah AA, Maksud M, Khan S, Lutfa L, Quraishi SB (2017) "Dietary intake of heavy metals from eight highly consumed species of cultured fish and possible human health risk implications in Bangladesh.

" Toxicology Reports 4:574-579. https://doi.org/10.1016/j.toxrep.2017.10.002

119. UNESCO (1976) from https://en.unesco.org/biosphere/aspac/miankaleh 
120. UNIDO (2003) (United Nations Industrial Development Organization) Removal of barriers to introduction of cleaner artisanal gold mining and extraction technologies. http://www.cetem.gov.br/gmp/GMP_News/GMP_News_January_2003.pdf

121. USEPA (1989) Risk Assessment Guidance for Superfund, Human Health Evaluation Manual Part A, Interim Final, I. United States Environmental Protection Agency, Washington DC

122. USEPA (2005) "U.S. Environmental Protection Agency,Office of Scienceand Technology, Office of Water) Water quality criterion for the protection of human health. Methyl mercury 2005. /http://www.epa.gov/waterscience/ criteria/methylmercury/document.htmlS."

123. USEPA (2005) Water quality criterion for the protection of human health: methylmercury. http://www.epa.gov/waterscience/criteria/methylmercury. Accessed 29 June 2005

124. USEPA (2011) "USEPA Regional Screening Level (RSL) Summary Table: November 2011."

125. USEPA (2012) "EPA Region III Risk Based Concentration Table." Philadelphia (PA (: United States Environmental Protection Agency, Region III

126. USEPA (2015) Regional Screening level (RSL) for chemical contaminant at superfound sites, U.S. Environmental Protection Agency: 176

127. USEPA (2017) National primary drinking water regulations, Retrieved from https://www.epa.gov/ground-water-anddrinking-water/national-primary-drinking-waterregulations

128. USEPA (2019) Regional screening levels (RSLs) - generic tables [WWW document]. Risk Assess. URL. https://www.epa.gov/risk/regional-screening-levels-rsls-generic-tables, Accessed date: 29 November 2019

129. Usero J, Izquierdo C, Morillo J, Gracia I (2004) "Heavy metals in fish (Solea vulgaris, Anguilla anguilla and Liza aurata) from salt marshes on the southern Atlantic coast of Spain. "Environment International 29(7):949-956. https://doi.org/10.1016/S0160-4120(03)00061-8

130. USFDA (2004) FDAandEPAAnnouncetheRevisedConsumerAdvisoryon MethylmercuryinFish

131. USNAS (2017) Using 21st Century Science to Improve Risk-Related Evaluations. National Academies Press, Washington, D.C.

132. Vahter M, Berglund M, Åkesson A, Liden C (2002) Metals and women's health. Environmental research 88(3):145-155. doi:10.1006/enrs.2002.4338

133. Varol M, Kaya GK, Alp A (2017) Heavy metal and arsenic concentrations in rainbow trout (Oncorhynchus mykiss) farmed in a dam reservoir on the Firat (Euphrates) River: Risk-based consumption advisories. Sci Total Environ 599:1288-1296.

https://doi.org/10.1016/j.scitotenv.2017.05.052

134. Varol M, Sünbül MR (2019) Environmental contaminants in fish species from a large dam reservoir and their potential risks to human health. Ecotoxicol Environ Saf 169:507-515. https://doi.org/10.1016/j.ecoenv.2018.11.060

135. Varol M, Sünbül MR (2020) "Macroelements and toxic trace elements in muscle and liver of fish species from the largest three reservoirs in Turkey and human risk assessment based on the worstcase scenarios." Environmental Research: 109298. https://doi.org/10.1016/j.envres.2020.109298 
136. Vrhovnik P, Arrebola JP, Serafımovski T, Dolenec T, Šmuc NR, Dolenec M, Mutch E (2013) Potentially toxic contamination of sediments, water and two animal species in Lake Kalimanci, FYR Macedonia: relevance to human health. Environmental pollution 180:92-100. https://doi.org/10.1016/j.envpol.2013.05.004

137. Walker C, Hopkin S, Sibly R, Peakall D (2001) "Principles of ecotoxicology. Taylor \& Francis, " Nueva York, pp 163-178

138. Wei R, Wang X, Tang W, Yang Y, Gao Y, Zhong H, Yang L (2020) Bioaccumulations and potential human health risks assessment of heavy metals in ppk-expressing transgenic rice. Science of The Total Environment 710:136496. https://doi.org/10.1016/j.scitotenv.2020.136496

139. Wennberg M, Lundh T, Bergdahl IA, Hallmans G, Jansson J-H, Stegmayr B, Custodio HM, Skerfving S (2006) "Time trends in burdens of cadmium, lead, and mercury in the population of northern Sweden. " Environmental research 100(3):330-338. https://doi.org/10.1016/j.envres.2005.08.013

140. WHO (1989) Heavy metals-environmental aspects. Environment Health Criteria No. 85, Geneva 141. WHO (2017) Guidelines for Drinking-water Quality, fourth ed. incorporating the firs taddendum. Geneva. https://apps.who.int/iris/handle/10665/254637

142. Xiao C, Jian H, Chen L, Liu C, Gao H, Zhang C, Liang S, Li Y (2017) Toxic metal pollution in the Yellow Sea and Bohai Sea, China: distribution, controlling factors and potential risk. Mar Pollut Bull 119(1):381-389. https://doi.org/10.1016/j.marpolbul.2017.03.027

143. Xu L, Wang T, Ni K, Liu S, Wang P, Xie S, Meng J, Zheng X, Lu Y (2014) "Ecological risk assessment of arsenic and metals in surface sediments from estuarine and coastal areas of the southern Bohai Sea, China" Human Ecological Risk Assessment: An International Journal 20(2): 388-401. https://doi.org/10.1080/10807039.2012.762281

144. Yılmaz F, Özdemir N, Demirak A, Tuna AL (2007) "Heavy metal levels in two fish species Leuciscus cephalus and Lepomis gibbosus. " Food Chemistry 100(2):830-835. http://dx.doi.org/10.1016/j.foodchem.2005.09.020

145. Zhao Y, Xu M, Liu Q, Wang Z, Zhao L, Chen Y (2018) Study of heavy metal pollution, ecological risk and source apportionment in the surface water and sediments of the Jiangsu coastal region, China: a case study of the Sheyang Estuary. Mar Pollut Bull 137:601-609. https://doi.org/10.1016/j.marpolbul.2018.10.044

146. Zhuang P, McBride MB, Xia H, Li N, Li Z (2009) "Health risk from heavy metals via consumption of food crops in the vicinity of Dabaoshan mine. South China" Science of the total environment 407(5):1551-1561. https://doi.org/10.1016/j.scitoten.2008.10.061

\section{Figures}




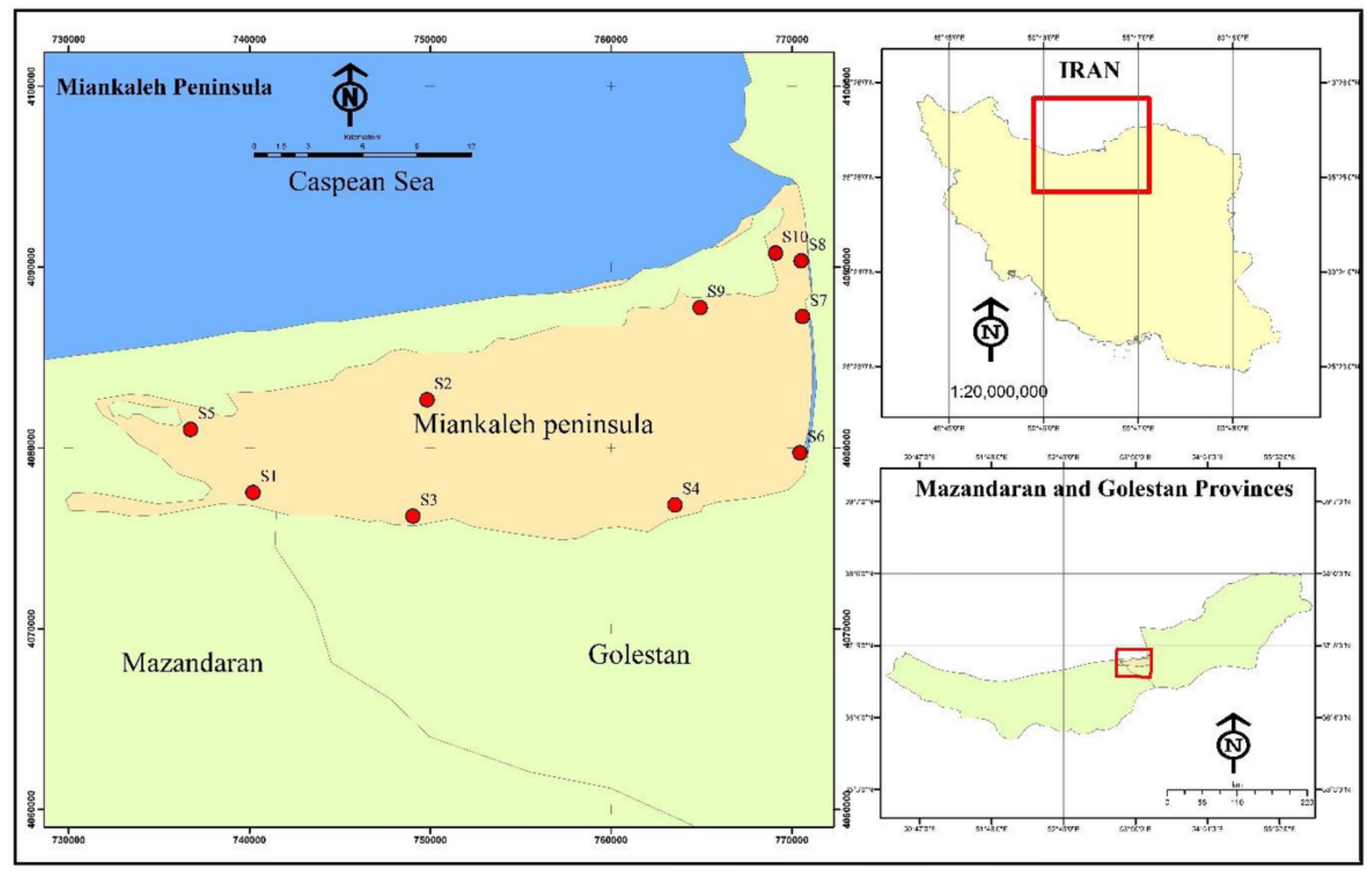

Figure 1

Distribution of water and sediment sampling stations in the study area

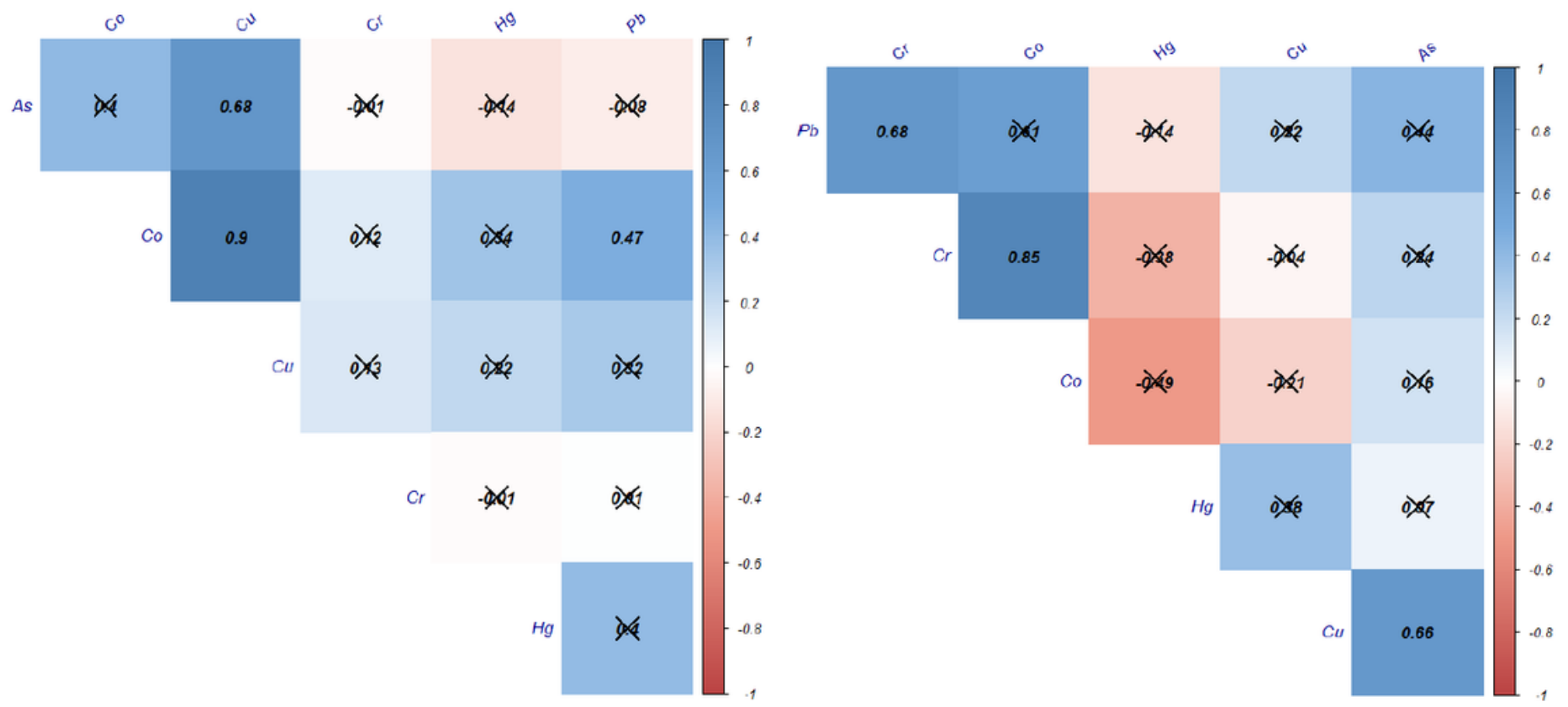

Figure 2 
Correlation test results between heavy metals in water (a) and sediment samples (b)
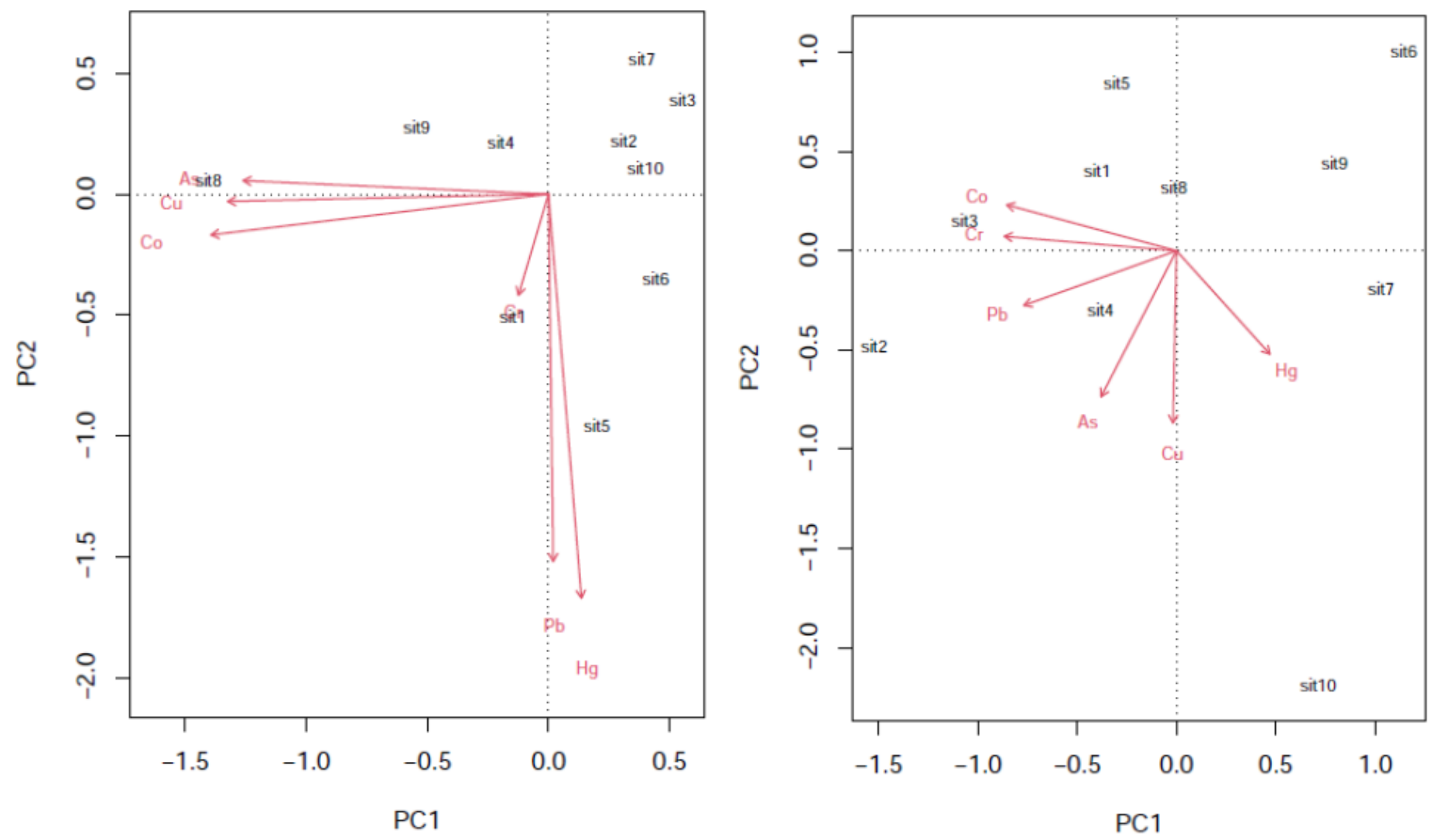

Figure 3

PCA biplot displaying heavy metals distribution between water (a) and sediment (b) samples
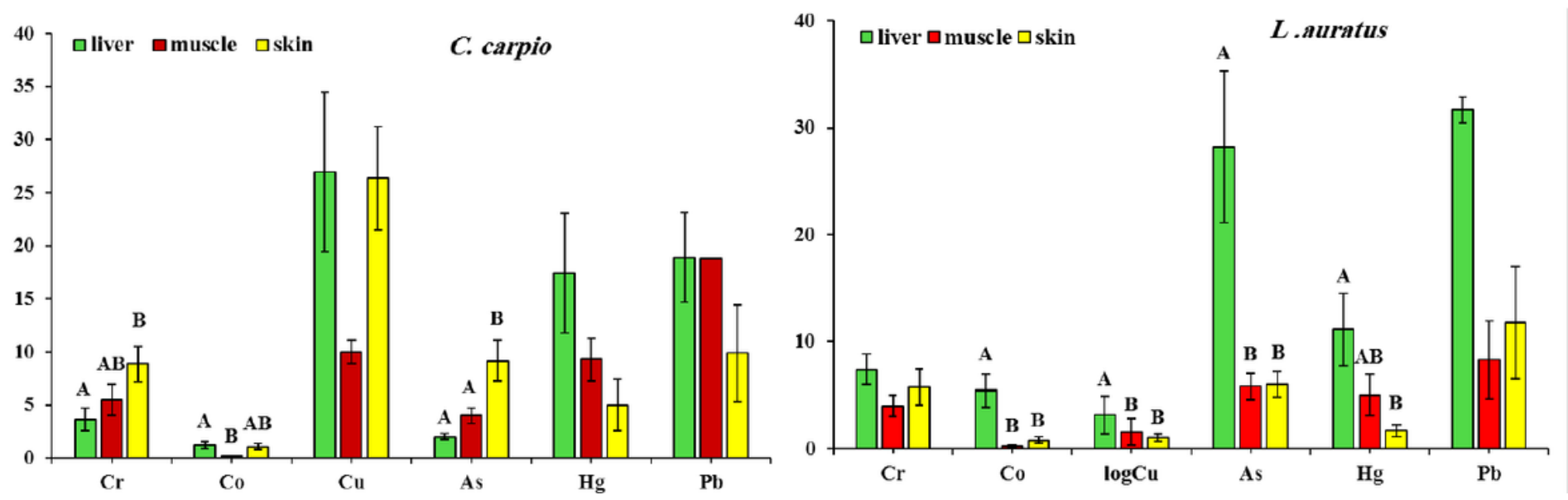

Figure 4

ANOVA test results between different fish tissues at a significant level of 0.05 Different letters indicate a significant difference 


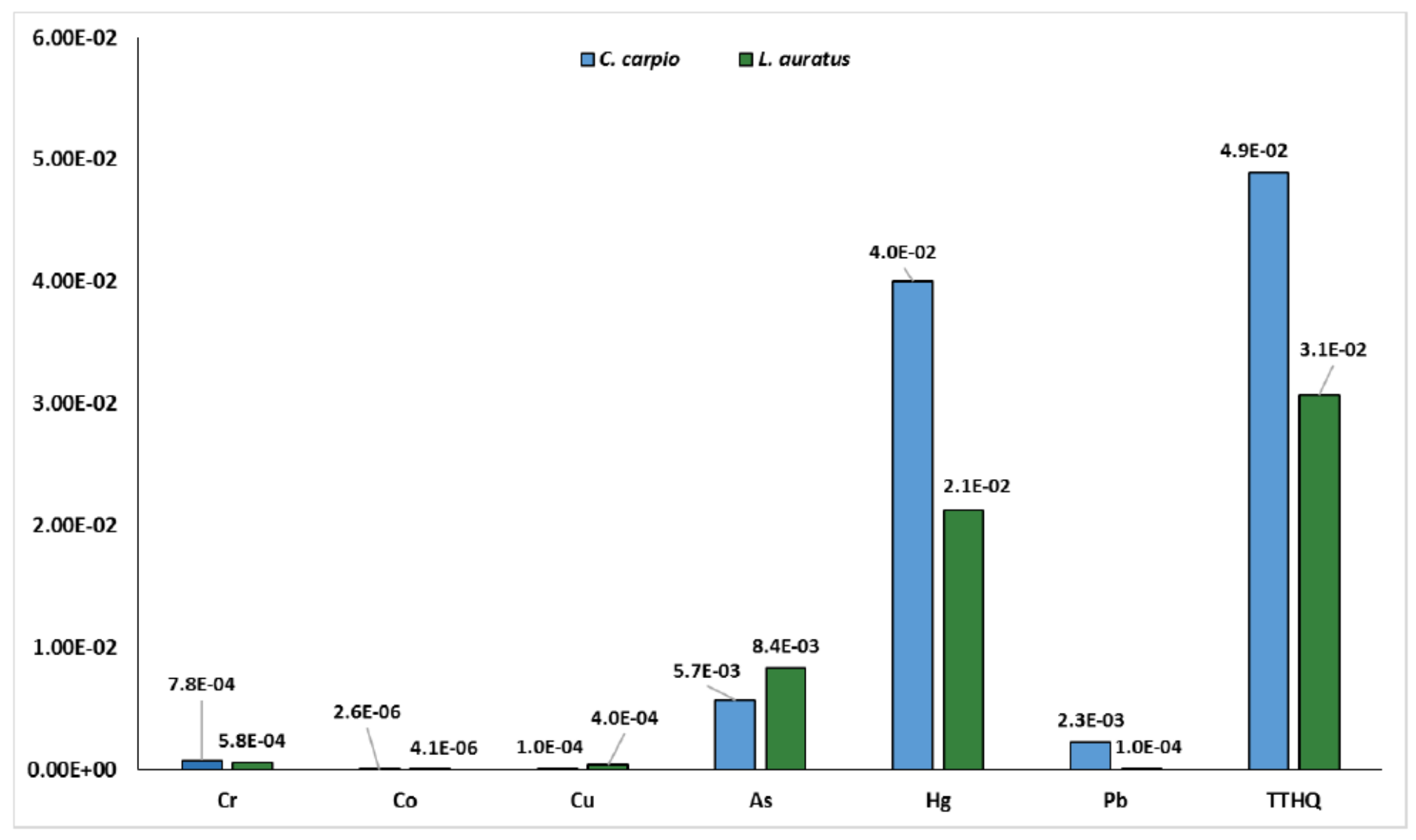

Figure 5

THQ and TTHQ values of heavy metals in muscles for each heavy metal in fish species

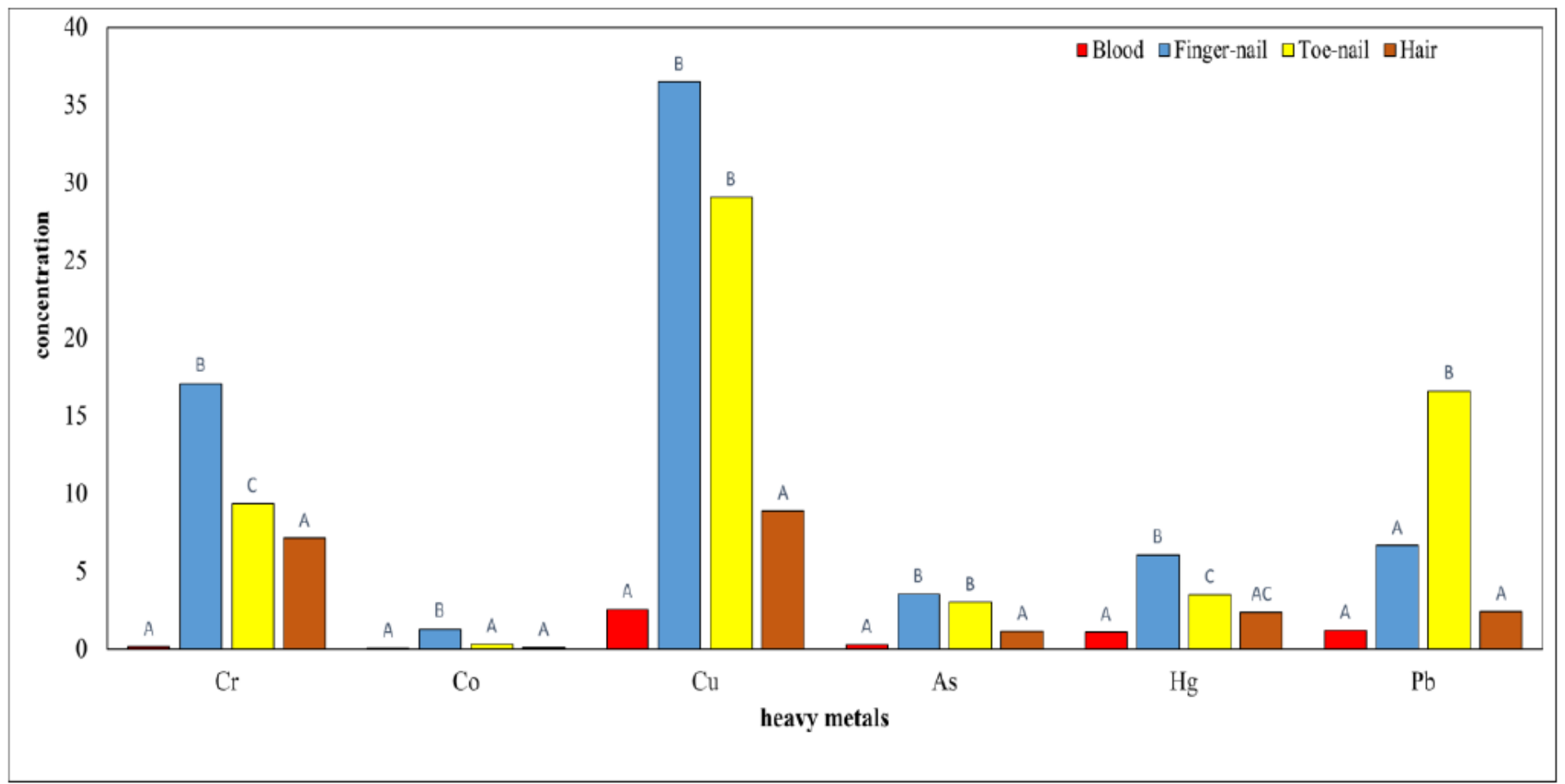

Figure 6 
ANOVA results between different fish organs in Turkmen pregnant women at a significant level of 0.05 (Different letters indicate a significant difference)

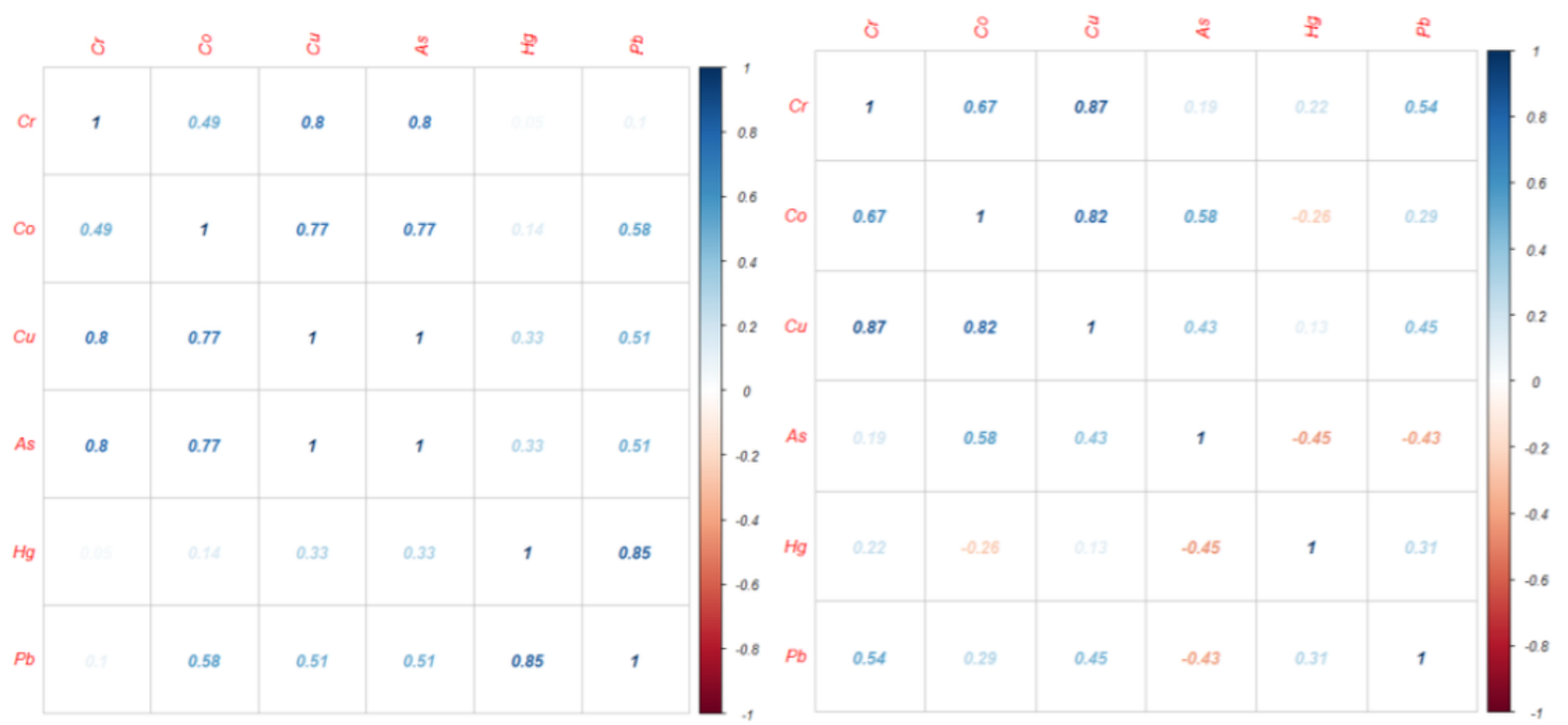

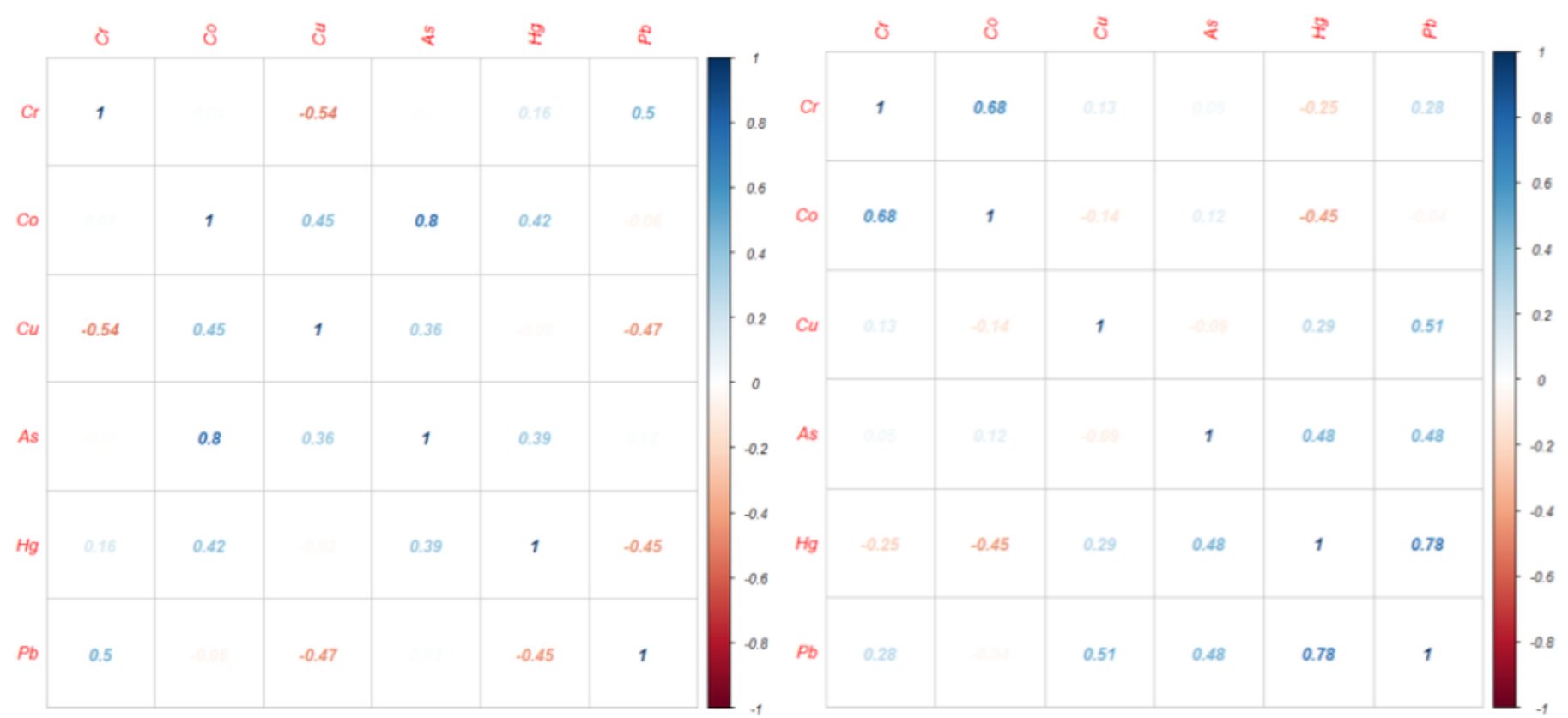

Figure 7

Correlation of heavy metals in blood samples (a), hair (b), fingernail (c), and toenail (d) 